\title{
TAX ELASTICITY AND PROGRESSIVITY for TURKISH TAX SYSTEM
}

\subsection{INTRODUCTION}

The impact of taxation on economic efficiency, income disparity and social welfare has been extensively studied both theoretically and empirically. This study intends to provide a comprehensive analysis of taxation in Turkey in two ways. First, a comprehensive analysis of some important aspects of the Turkish taxation is discussed by challenging some common arguments claimed in the previous studies. For example, Turkey's indirect tax revenue is 50 percent of total tax revenue, which is remarkably greater than the OECD average of 32 percent - see to OECD (2017). Has this always been the case, or is it a recent phenomenon observed as a result of the extensive liberalisation since 1980 as claimed by Köse and Yeldan (1998), Demir (2004), Arıkboğa (2011) and Arıkboğa (2015)? Second, this study explores issues which are worth clarifying regarding the Turkish tax system, in particular in the light of the graduation of Turkey to an upper-middle income country - see WorldBank (2017a). These questions are: how has the tax burden evolved over time compared to similar European economies? How has progressivity of Turkish tax system changed over time? How did sales tax cuts implemented during the 2009 crisis affect the consumer welfare?

Departing from other studies which analysed the Turkish tax system, such as Mucuk and Alptekin (2008), Açikgöz (2008) and Durkaya and Ceylan (2006), this study uses the longest available dataset on tax revenue, which starts with 1924 and ends with 2016. Furthermore, while the aforesaid studies built their analyses on indirect and direct tax classification, this study disaggregates the tax revenue data into four groups: income tax, wealth tax, sales tax and import tax. These studies focused on tax revenue composition and its impacts on economic growth by applying dynamic time-series models like VAR models or Granger causality tests. Although they used the time-series data and derived tax elasticity figures, the studies above did not expand their analyses to cover tax progressivity. By contrast, this study takes a step to expand tax elasticity discussions by including tax progressivity, as presented in section 1.4. According to our knowledge, this is the first time that the 
tax progressivity is analysed with time-series data, so enabling us to observe the evolution of tax progressivity for the Turkish tax system.

The analysis in this study starts with an investigation of the historical tax revenue data to reveal the evolution of the tax burden compared to some developed economies in OECD. The analysis is followed by the investigation of indirect taxes with historical data starting from 1924 and ending with 2016. The change in decomposition of the indirect tax revenue is tested by applying Lorenz dominance. The following two subsections assess the Turkish tax system by deriving long and shortrun tax elasticity figures in respect to income, as well as tax progressivity indices based on the study by Kakinaka and Pereira (2006). In the first place, time-series characteristics of the data is checked and the presence of a long-run relationship between different tax revenue types and the GDP is tested (see Appendix for cointegration test results). After confirming the presence of a long-run relationship, short and long-run tax elasticity figures with respect to income are derived. Following this, it is shown that the Turkish tax system has become less progressive over time. In the last section, the effects of tax cuts imposed in 2009 are discussed with regard to consumer welfare.

\subsection{STYLISED FACTS ON TAXATION IN TURKEY}

This section provides a chronological analysis of some important figures related to taxation in Turkey. The first subsection looks at the evolution of the tax burden for the Turkish economy and compares it with developed European economies. The second subsection carefully analyses chronological changes in the proportion of direct and indirect taxes on the total tax revenue. The third part (subsections 1.2.3 and 1.2.4.) conducts a more technical analysis to obtain tax elasticity and tax progressivity measures.

\subsubsection{Evolution of Total Tax Revenue in GDP}

The first stylised fact of taxation in Turkey regards its share in the GDP: it has been steadily increasing, i.e. the tax burden in Turkey becomes more similar to developed economies. For comparison, three Mediterranean economies, Spain, France, and Italy are selected due to having close 
real GDP figures to Turkey, according to World Bank real GDP rankings see - WorldBank (2017b). Also, these economies have tax regimes based on principles similar to the ones used for Turkey. For instance, their constitutions openly state concepts of ability to pay principle, and the importance of a social welfare state as stated in Gök, Biyan, and Akar (2015) and Tiffin and Salois (2015). The UK is also considered as one of the neoliberal economies among OECD countries. Figure 1 illustrates the increasing share of the total tax revenue in GDP, among the chosen countries.

Figure 1: Tax Revenue, Percentage of GDP, 1965 - 2016

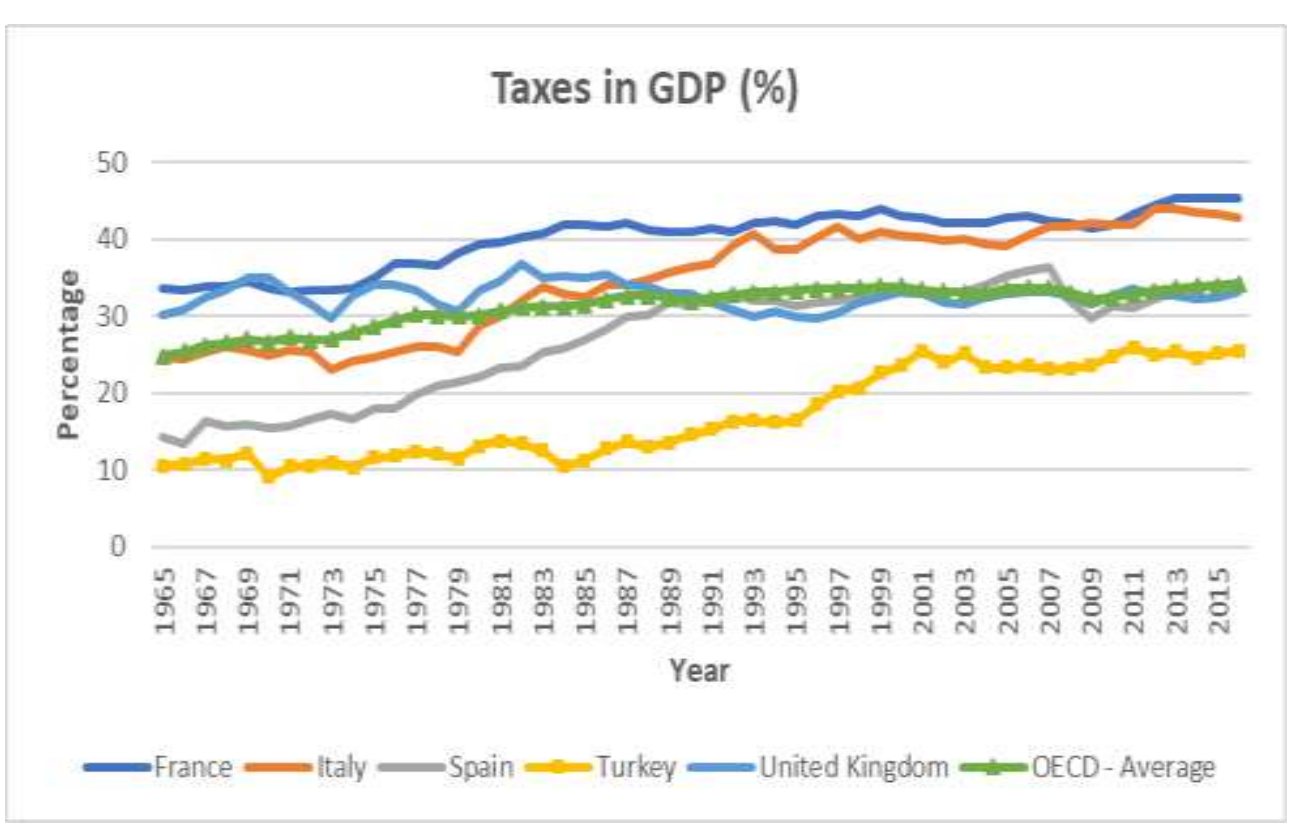

Data from OECD Statistics Taxation. Last Access: 25.11.2017

As seen in Figure 1, Spain and Turkey were closer during 1960s and Spain surpassed the OECD average over time. Tax burden of Italy, which is just ranked on top of Turkey in terms of real GDP as of 2016, see WorldBank (2017b), corresponds in 2016 to roughly 45 percent whereas Turkey's tax burden is almost 25 percent. For Turkey, the first time that trend distinctively moved upward corresponds to 1985, when VAT was introduced. On the other hand, the gap between Turkey, and Spain with the UK has started to narrow down from 1999 onwards. Between 1998 and 2001 the Turkish economy experienced several economic crises which were overcome also thanks to the IMF's financial assistance - which eventually ended up with a series of austerity measures imposing tax 
increase, public spending cuts, and extensive privatisations, see Yeldan (2006), Önis (2006), and Evrensel (2004). Additionally, the informal economy and incentives for gaining an advantage in tax competitiveness can be considered as other possible reasons for historically lower tax burden. Although Schneider $(2013,2015)$ consistently reported Turkey with one of the highest informal economies among European economies, the same studies also show that its level has gradually declined, and this leads to an increase in total tax revenues. Additionally, the proliferation of credit card use was discussed in the previous chapter. It appears that using cards has helped to decrease size of the informal economy. Pomerleau (2017) shows that Turkey was ranked tenth economy among 35 OECD countries in terms of tax competitiveness, as of 2015. However, the same study argues that Turkey retreated by two places after 2013 and this appears to be consistent with the increasing tax burden.

The Figure 1 can be expanded by examining the increase of different tax types from 1924 onwards. Figure 2 below shows trends of tax revenues obtained from different taxes.

Figure 2: Evolution of Tax Revenue per Tax Type

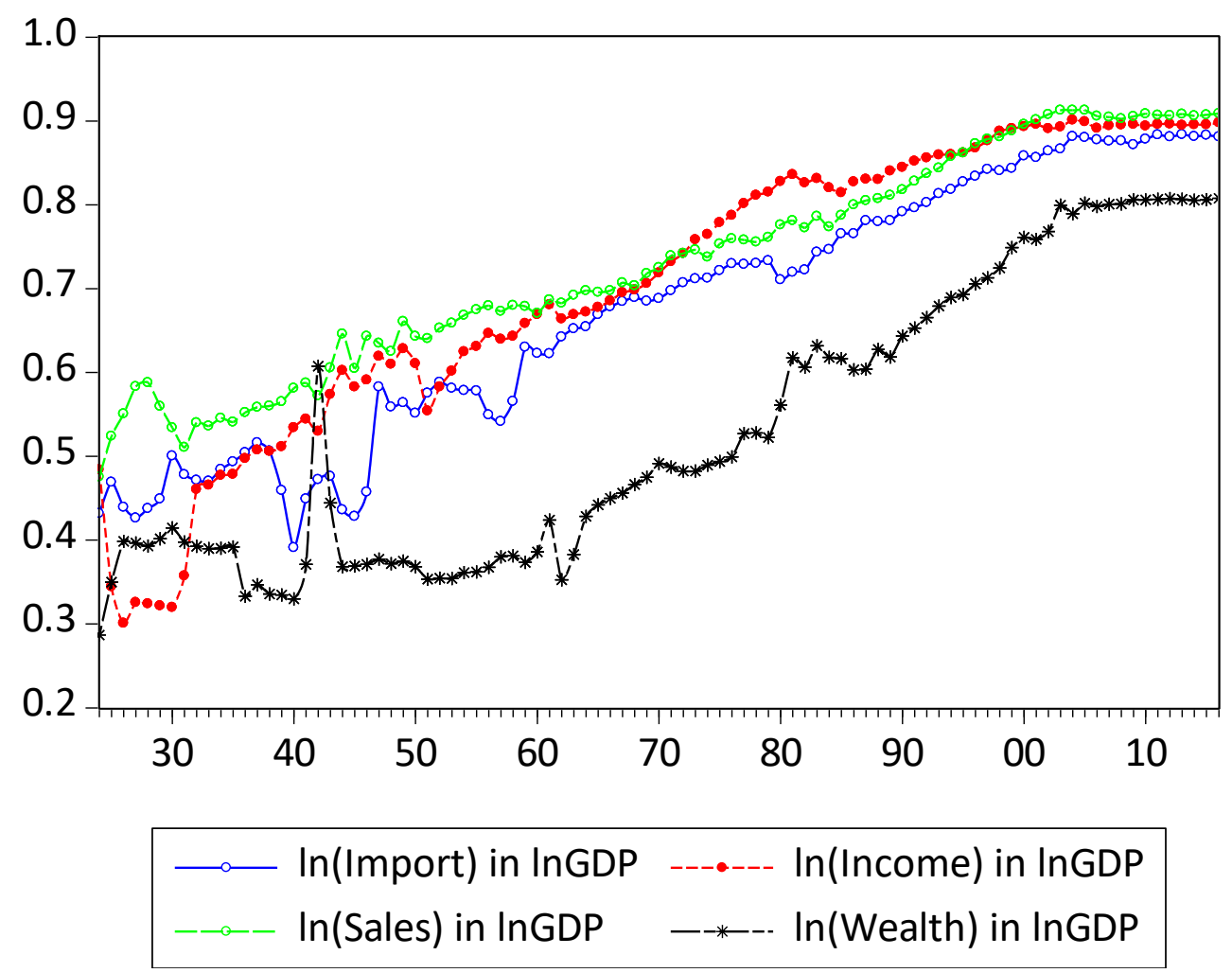


Data $^{1}$ from General Directorate of Budget and Fiscal Control, Budget Figures and Budget Realization, Budget Figures since 1924. Last Access: 23.11.2017.

As shown in Figure 2, the fastest increase is observed in income, sales and import taxes, while the wealth tax revenue rose relatively more slowly. In other words, the indirect taxes (sales and import taxes) increased faster than the direct taxes (income and wealth taxes). The next subsection investigates this issue by addressing possible reasons.

\subsubsection{Direct vs Indirect Taxes}

The second stylised fact about the Turkish tax system is on the tax revenue composition; the largest component of the general ${ }^{2}$ budget tax revenue is obtained through indirect taxes, which mainly cover sales and imports. For instance a study by Demir (2004) states that 'The share of indirect taxes in total tax revenues increased from 37.2\% to 59.6\% during 1980-2001.' Although these figures are accurate, the author claims that this was a result of economic liberalisation and misses to investigate pre-1980 period for the share of indirect in total tax revenue. In a similar manner, several other studies, e.g. Arıkboğa (2011) and Arıkboğa (2015), linked dominance of the indirect taxes in the general budget tax revenue to the economic liberalisation which has been taking place since 1980s for more information on the liberalisation of the Turkish economy, see Rodrik (1990), Rittenberg (1993), Günçavdı, Bleaney, and McKay (1998) and Boratav and Yeldan (2006). Accordingly, the

\footnotetext{
${ }^{1}$ Budget statistics of Turkey has two levels: central and local. Central government budget is equal to the sum of general government agencies (e.g. ministries, the supreme court etc.), special budget agencies (universities etc. as these institutions are legally permitted to generate other types of income apart from tax income transferred by government) and regulatory bodies (energy markets, banking sector etc.) and social security institution. Local government budget, as the name suggests, belongs to local governments. The budget data employed here only covers the budget of the general government agencies, i.e. the authority which collects the largest part of the tax revenue. OECD reports the same data under level of central government, from 1980 onwards. However, the same data is available via Ministry of Finance, General Directorate of Budget and Fiscal Control from 1924 onwards. For an explanation of budgeting in Turkey see Kraan et al. (2007), p. 14.

${ }^{2}$ General tax revenue is the largest part of the total tax revenue. For details, see above the footnote 1.
} 
intensive liberalisation of macroeconomic policy resulted in a shift in tax revenue composition in favour of indirect taxes, because of a deliberate limitation of direct taxes collected from income, profit, and property to support capital accumulation and the growth of the private sector. Although the dominance of indirect taxes in general budget tax revenue was evident from 1980s onwards, linking this to the macroeconomic liberalisation (aforementioned studies prefer to call this period as 'neoliberal transformation') rests on a misleading premise. Contrary to this argument, once the general budget tax revenue composition is traced back to beginning of the Republic of Turkey in 1923 (which is not done by the aforementioned studies), it is seen that the share of the indirect taxes has historically been greater than that of the direct taxes. Besides, as it will be discussed soon, motivations for maintaining dominance of indirect taxes in the general budget tax revenue have changed over time. Figure 3 below presents the share of indirect taxes (levied on sales and import) in the general budget tax revenue.

Figure 3: Share of Indirect Taxes in General Budget Tax Revenue, 1924 -2016

Indirect Taxes in Total Tax Revenue

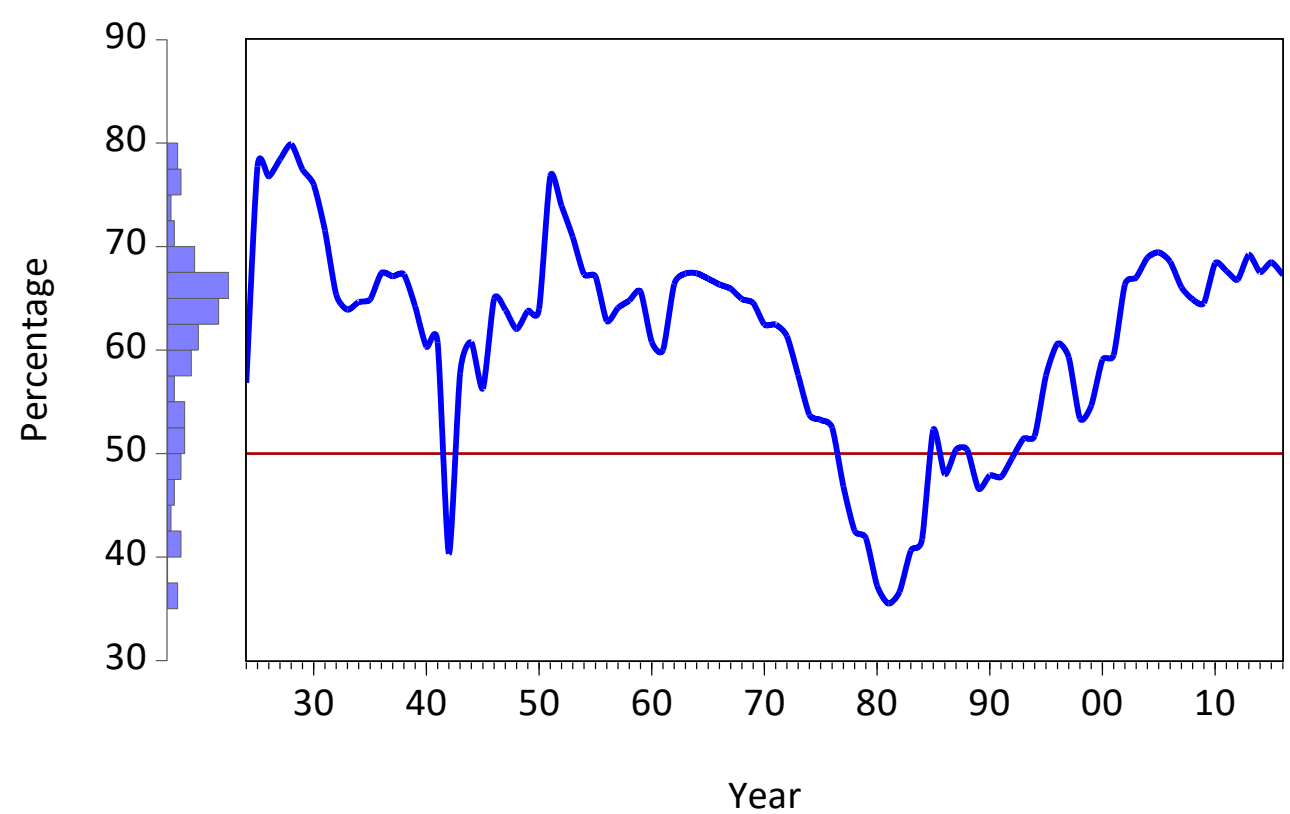

Data from General Directorate of Budget and Fiscal Control, Budget Figures and Budget Realization, Budget Figures since 1924. Last Access: 23.11.2017. 
As shown by Figure 3, the share of indirect taxes falls below 50 percent only in two periods, for less than 10 years out of 92 . These periods correspond to periods of political and economic turmoil when consumption declined and hence the tax revenue collected from consumption did. The first time was a two-year period during the Second World War, and the second time was between 1977 and 1984, when Turkey was severely hit by foreign exchange and debt crisis, ${ }^{3}$ see Dervis and Robinson (1982), Lewis and Urata (1984), Rodrik (1990) and Boratav (2008), and underwent a political turmoil which led to the 1980 coup d'état. Otherwise, the average budget share of indirect taxes in the general budget tax revenue has been around 60 percent and the median has been 64 percent (as shown by histogram on the left axis of Figure 3 ). The share later started to increase following the introduction of the value-added tax at the beginning of 1985 - see Rodrik (1990).

The motivations behind the indirect tax regime seems that tax composition is used to redistribute resources, as argued by Wagner (1958). He discusses two purposes of taxation: purely financial (to finance state expenditure) and social welfare (redistribution of resources). The first ten years of the republic were characterised by laissez-faire policy attitude, as described in Takim and Yilmaz (2010) and Finefrock (1981), where the redistributive power of taxation was used in favour of the private sector. Fiscal policy in the early years of the republic deliberately supported capital accumulation, which is the main source of long-term economic growth in Turkey - see Altug, Filiztekin, and Pamuk (2008). As Ergil (1975) stated, the agricultural sector was the largest part of GDP by production., However, it was subject to limited capital and profit taxation compared to other sectors during the 1950s, even though étatism had been adopted from 1932 onwards - see Birtek (1985) and Finefrock (1981).

So far it is seen that dominance of indirect taxes in the general budget tax revenue was not a recent trend as claimed by the aforementioned studies, but it was a long-term tendency. One of the

\footnotetext{
${ }^{3}$ Severity of debt crisis was partly due to economic isolation and US embargo between 1975 and 1978 as a consequence of Turkey's military intervention to North Cyprus in July 1974.
} 
reasons seems to be encouraging capital accumulation to empower the private sector. Another inadequacy of the above studies is that they tackle indirect taxes all together and omit decomposition of total tax revenue and share of different types of indirect taxes in it. Indirect taxes are collected from sales, and from imports. Figure 4 below presents the share of import and sales.

Figure 4: Share of Different Indirect Taxes in Total Tax Revenue, 1924 - 2016

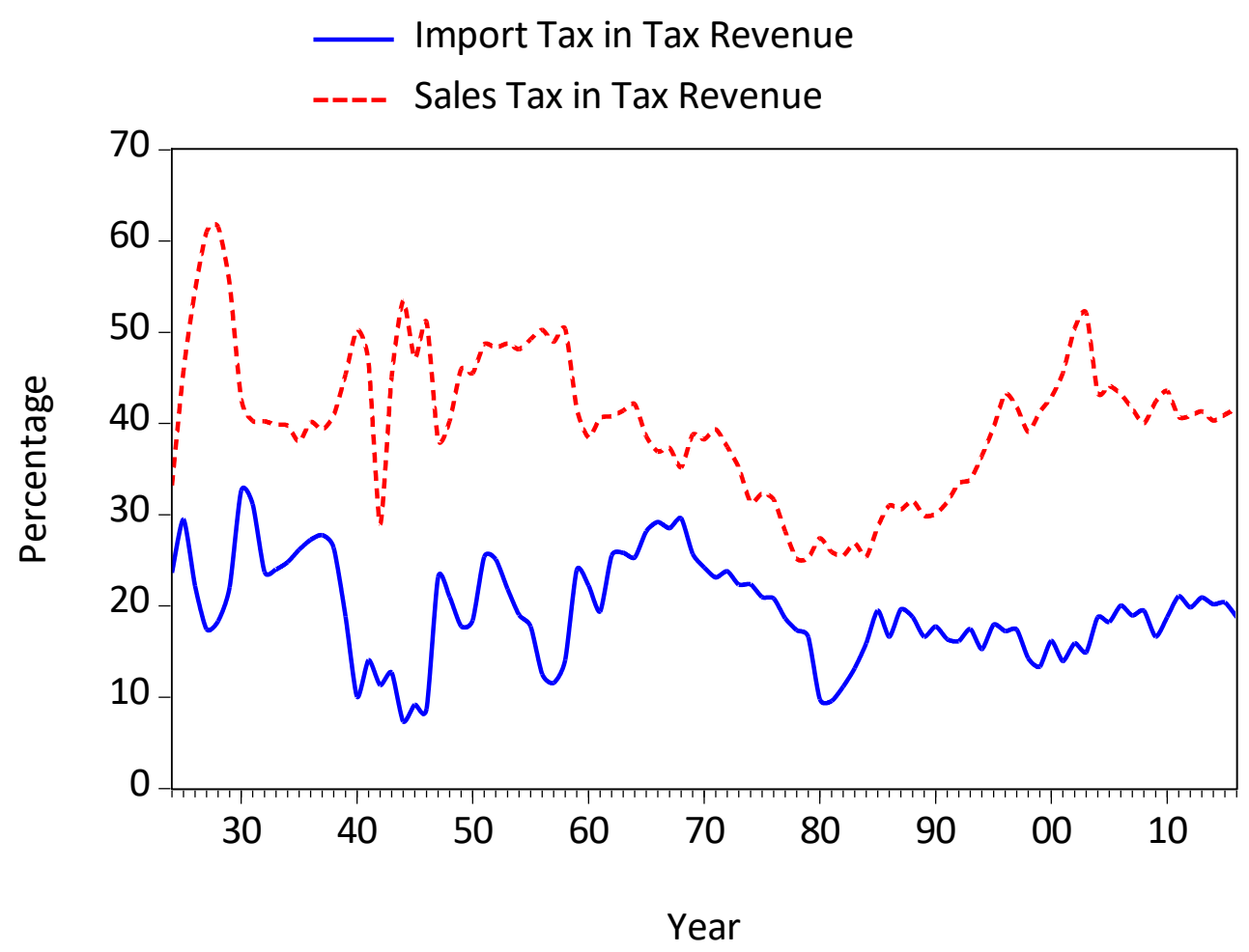

Data from General Directorate of Budget and Fiscal Control, Budget Figures and Budget Realization, Budget Figures since 1924. Last Access: 23.11.2017.

Excluding the period of the Second World War and the economic crisis of 1978, the two curves appear to be negatively correlated. This makes sense since pre- and post-1980 periods refer to two different macroeconomic approaches for Turkey's overall economic policy. As Yeldan (1989) describes, the period between 1960 and 1980 was ruled by planned development policy and a strict import substitution regime was followed. The import tax was deliberately used to discourage imports. Consistent with this policy, the share of the import tax in indirect tax revenue was over 20 percent until 1980. However, the post-1980 period witnessed an intensive economic liberalisation affecting 
imports and exports - see Rodrik (1990) and Baysan and Blitzer (1990). As seen in Figure 4, after the coup of 1980 , while sales tax restored back to its average share over 40 percent, the share of the import tax has never exceeded 20 percent again. In 1996, Turkey became a member of the Customs Union and this increased the loss of import tax revenue, as previously shown by Mercenier and Yeldan (1997). The study by Yilmaz (2011) claims that the loss of import tax revenue was a short-term effect, but a downturn in import tax revenue growth from 1996 onwards is observed in Figure 5 considering that Europe has the largest share in international trade of Turkey - see Antonucci and Manzocchi (2006).

Figure 5: Import Expenditure Growth (\%) vs Import Tax Revenue Growth (\%)

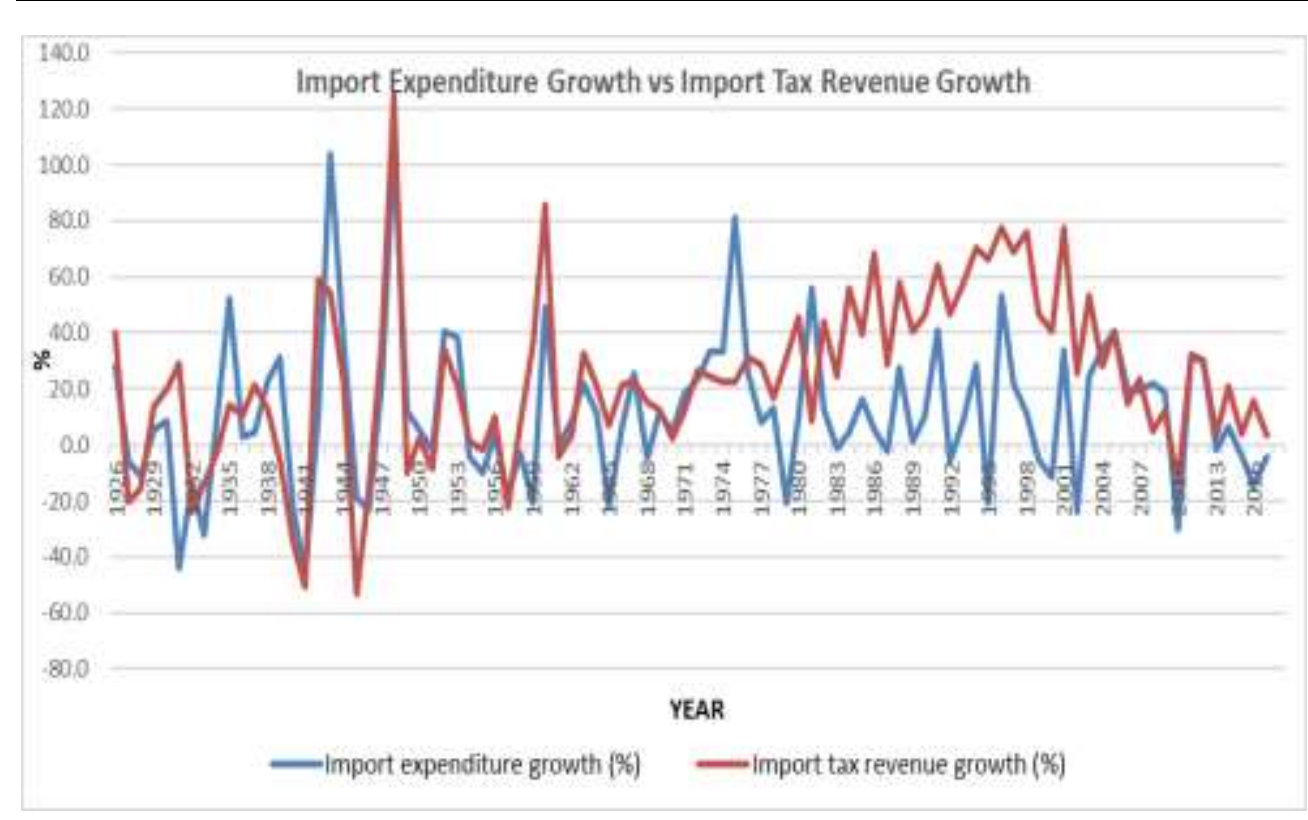

Data from TURKSTAT International Trade Statistics. Last Access 22.01.2018.

Figure 5 shows the changes in import expenditure and import tax revenue between 1926 and

2016. It can be noticed that the simultaneous cycles of growth of import expenditure and of import tax revenue were distorted between 1983 and 2004. While the import tax revenue growth was escalating between 1983 and 1995, the trend turned downward from 1996 onward, following Turkey's participation in the Customs Union. It can be said, import tax revenue initially grew faster than import expenditure due to increasing import volume with the help of trade liberalisation. But after Turkey 
adopted the common external trade policy of Europe, the growth of import tax revenue lost its acceleration. In this regard, it can be said that the macroeconomic liberalisation did not affect the overall share of indirect taxes. But the revenue composition obtained from indirect taxes, so the motivations behind the indirect taxes, had changed.

This argument is further investigated by analysing the revenue generated from sales and import taxes over time. As shown in Figure 6, there are three different periods. Until 1961, sales tax revenues are greater than import tax revenue. Remarkable fluctuations during the Second World War is observed in import tax revenue. Following period corresponds the term when the import substitution policy was implemented, import tax revenue and sales tax revenue were almost equal. From 1980 onwards, revenue growth for both tax types accelerated (i.e. the curve became steeper) but the tax revenues started to diverge: sales tax revenue became dominant.

Figure 6: Sales Tax and Import Tax Revenue (In), 1924 - 2016

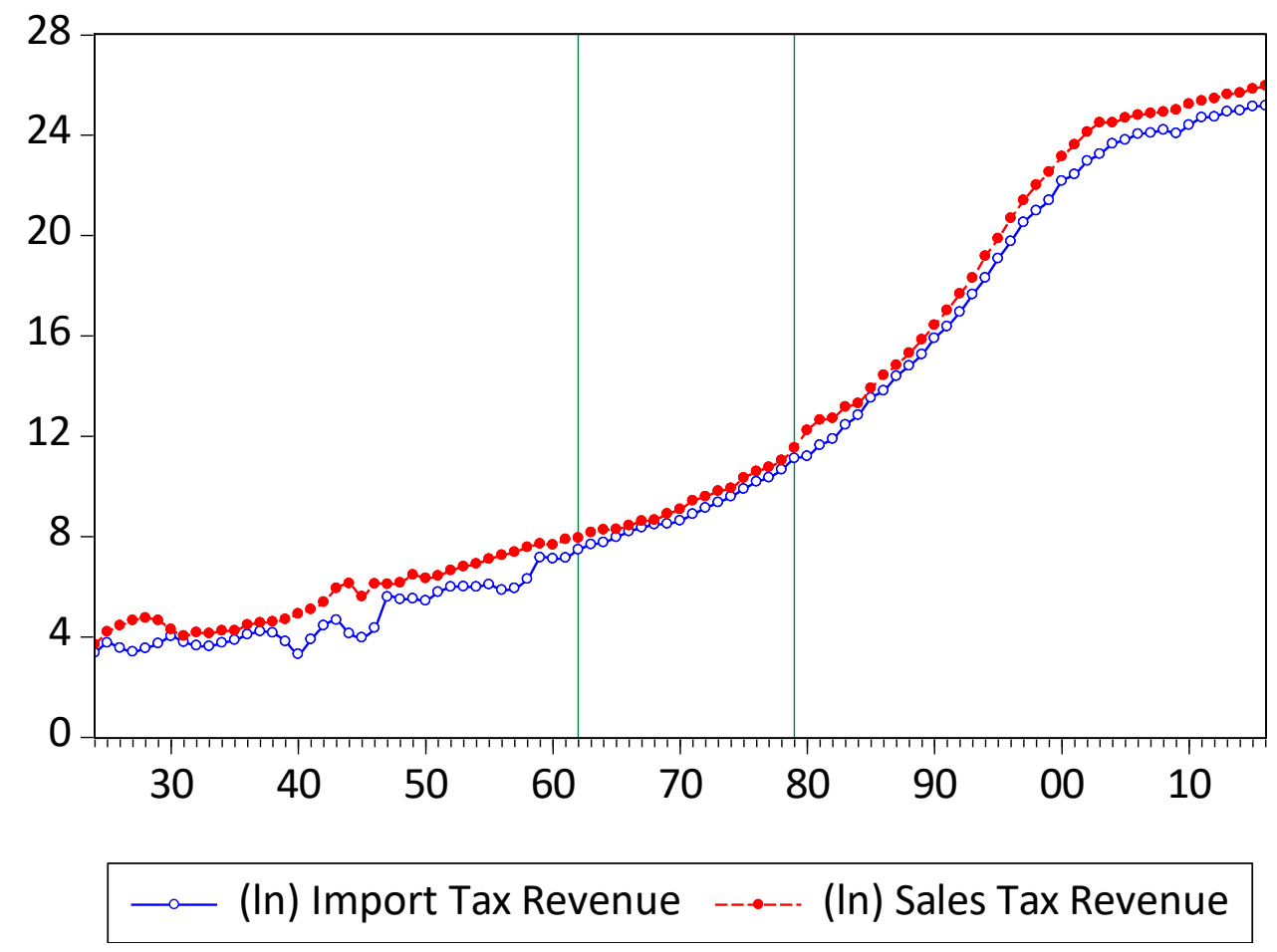

Data from General Directorate of Budget and Fiscal Control, Budget Figures and Budget Realization, Budget Figures since 1924. Last Access: 23.11.2017. 
The statistical significance of these periods can be examined by employing Lorenz dominance of sales tax revenue over import tax revenue. Following Atkinson (1970), if the difference between area under (In) sales tax revenue curves and area under (In) import tax revenue curves is positive and statistically significant, it can be concluded that sales tax revenue dominates import tax revenue for a given period of time. The analysis is conducted by using 95 percent confidence interval, which is presented by shaded areas.

Figure 7: Dominance of Sales Tax Revenue over Import Tax Revenue

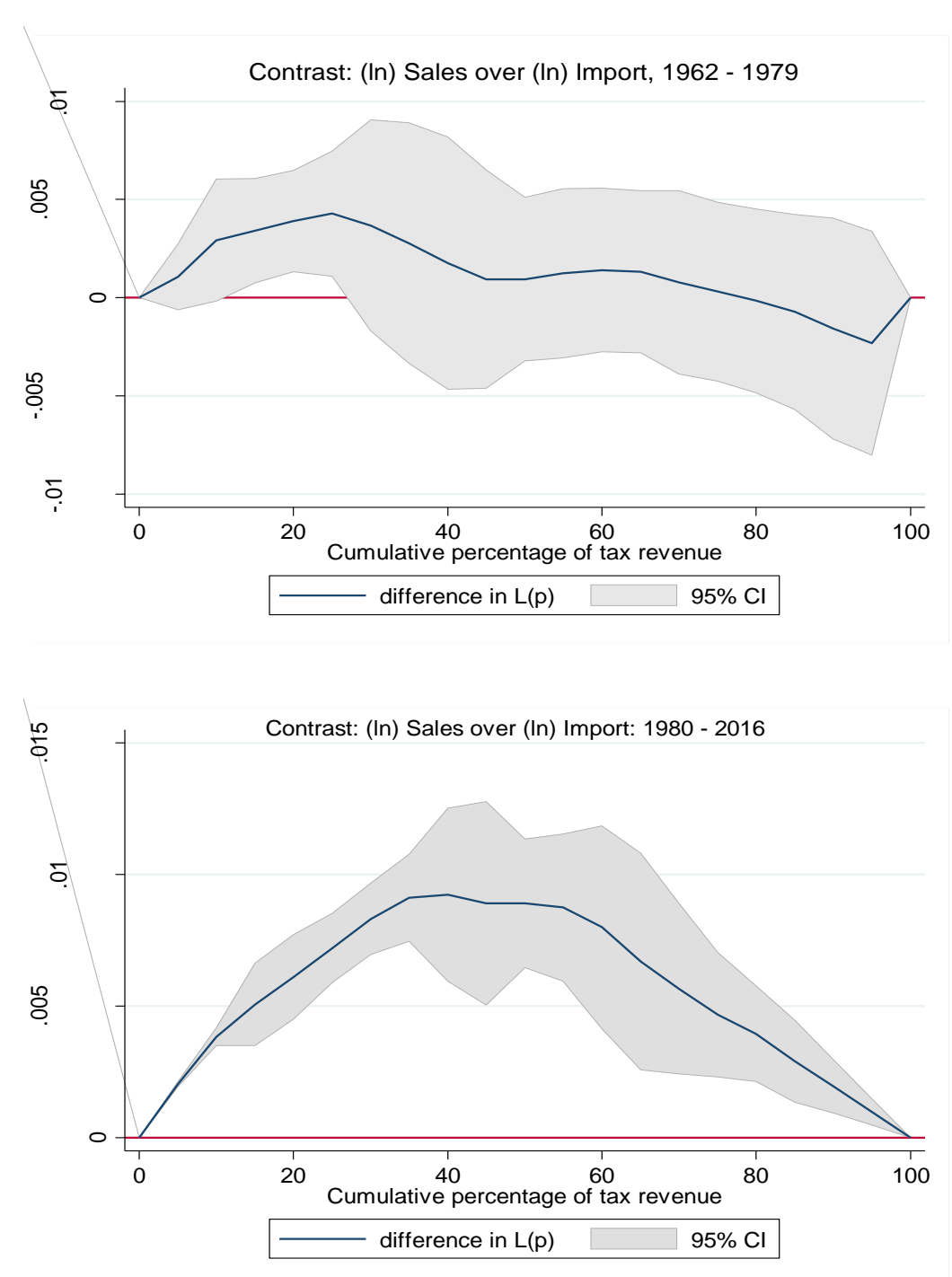

Data from General Directorate of Budget and Fiscal Control, Budget Figures and Budget Realization, Budget Figures since 1924. Last Access: 23.11.2017. 
Once Figure 7 is analysed, it is noticed that it is not possible to confirm dominance of the sales tax revenue over import tax revenue during the import substitution policy is implemented: the difference between the two curve was either zero or allowing import tax revenue to be greater than sales tax revenue (i.e. the contrast curve is not strictly above zero). However, Figure 7 also shows that following intensive liberalisation, the sales tax revenue dominated the import tax revenue (i.e. the contrast curve is always above zero) based on a 95 percent confidence interval.

To conclude, the Turkish tax system has continuously been dominated by indirect taxes. Nevertheless, the weight of import tax or sales tax in indirect tax revenue varies over time based on the macroeconomic policies implemented. The next subsection investigates the motivations behind the tax revenue composition in Turkey regarding tax elasticity.

\subsubsection{Tax Elasticity}

Total tax revenue is sensitive to the changes in GDP, and each type of tax differently responds to the fluctuations in GDP - see Mansfield (1972). Nonetheless, a dubious statement is made by Albayrak (2011). The study by Albayrak (2011) is relevant here as it is the only study that analysed the impact of the 2009 tax cuts on the income distribution by applying tax progressivity indices. Her analysis begins with arguing that the percentage of the total tax revenue over GDP does not significantly decrease during the 2009 economic crisis since the largest part of the tax was collected from consumption, which was protected by the credit boom from the financial crisis of 2009 - for more information on the credit boom see, Orhangazi (2014) and Karacimen (2014). Albayrak (2011) supports her argument by tabulating total tax with disaggregated major taxes and household credit burden in GDP. The paper demonstrates that all types of taxes and household credit burden increased in absolute terms during the 2009 crisis.

However, focusing on the share of the tax revenue on GDP is misleading if the responsiveness of the tax revenue to fluctuations in GDP is investigated: during the crisis the GDP had significantly fallen. Even if the tax revenue remains the same, the share would be increasing. The argument by 
Albayrak (2011) is theoretically problematic as well. If there is no meaningful relationship between the GDP and the total tax revenue, then the fiscal policy becomes an ineffective macroeconomic tool. To recall, Keynes (1936) addressed an essential role of taxation in an economy; in his own words, "The State will have to exercise a guiding influence on the propensity to consume partly through its scheme of taxation..." (ibid. p. 238), which emphasised the role of taxation as a macroeconomic tool for regulating business cycles. In this frame, previous studies by Durkaya and Ceylan (2006), Mucuk and Alptekin (2008) and Çiçek and Elgin (2011) investigated the role of taxes with tax revenue composition on GDP growth for the Turkish economy. Durkaya and Ceylan (2006) found a significant, positive, and bilateral Granger causality between direct taxes and the GDP growth. The study by Mucuk and Alptekin (2008) found a positive and significant Granger causality only from indirect taxes to GDP growth. Lastly, Çiçek and Elgin (2011) demonstrated that taxes have a distortionary effect on GDP growth by employing a static general equilibrium model. Although the results are conflicting, all of them acknowledge a relationship between the total tax revenue and GDP.

Departing from Albayrak (2011), who discussed fiscal policy on the basis of average tax burden, this paper employs the tax elasticity concept which measures responsiveness of tax revenue to changes in GDP. Before starting the discussion on tax elasticity figures, it is useful to clarify the relationship between tax elasticity and tax buoyancy and why this chapter mainly investigates the former. Tax elasticity illustrates sensitivity of a tax system or an individual tax to the fluctuations in GDP once there is no discretionary change in the fiscal policy (i.e. tax rates, exemptions, etc. remain the same). However, tax buoyancy reveals responsiveness of tax revenue to GDP when there are discretionary changes in the fiscal policy - see Mansfield (1972), Morrissey (1995), and Dudine and Jalles (2018). In this paper, the analysis is conducted for a 92-year period which has witnessed a series of changes in fiscal policy not just stemming from economic dynamics but also due to regime changes following coups. It should also be noted that primary aim of this subsection is not to analyse response of tax revenue to specific tax policy change. Therefore, tax buoyancy is left to further research. 


\subsubsection{Calculating Tax Elasticities}

Tax elasticity is measured by the formula given below, as stated in Dudine and Jalles (2018):

$$
\frac{\% \Delta T R}{\% \Delta G D P}
$$

The formula (1.1) basically is a ratio calculated by dividing the percentage change in total tax revenue (TR) into percentage change in GDP (here GDP is assumed to be the tax base). This can be rewritten as an equation which will be estimated via a linear regression analysis again following Dudine and Jalles (2018):

$$
\ln T R=c+\beta(\ln G D P)+\varepsilon
$$

The logarithmic transformation of the dependent and independent variables allows us to calculate a percentage change. Thus, the $\beta$ parameter directly provides the income elasticity of the corresponding tax revenue. The model can be expanded by adding time dummies to explore variations in tax elasticities over time. Also, the tax elasticity can be calculated regarding consumption or profit, instead of national income; for instance Creedy and Gemmell (2008) calculated corporate tax elasticity in respect to profit. In this paper, income tax refers to the taxes levied on personal income and corporate income (profit) together. Due to using an aggregate figure for income in this thesis, the tax elasticity is calculated in respect to income. As to the sales tax, household total consumption could have also been used but, as mentioned in previous chapters, marginal propensity to consume for Turkish economy is close to 70 percent. Given this high correlation between income and consumption, the sales tax elasticity is also calculated in respect to income.

The usual time-series model specification tests for the unit roots are conducted for the estimation, and results are reported below in Table 1. Visual inspection of the series - see Figure 11 in the Appendix - suggests estimating the unit root tests at level by including a constant and trend term. Regarding Figure 12 in the Appendix, the unit root tests are conducted on the first-differenced series without adding a constant or a trend term. 
Table 1: ADF and PP Unit Root Tests, at Level and First-differenced

\begin{tabular}{|c|cc|cc|cc|cc|}
\hline \multicolumn{8}{|c|}{ ADF Unit Root Test Results } \\
\hline $\begin{array}{c}\text { (In)Tax Revenue \& } \\
\text { (In)GDP }\end{array}$ & Akaike & Prob. & Schwarz & Prob. & Akaike & Prob. & Schwarz & Prob. \\
\cline { 2 - 10 } & -2.804 & 0.200 & -2.169 & 0.501 & -7.656 & 0.000 & -8.819 & 0.000 \\
\hline GDP & -1.552 & 0.804 & -1.552 & 0.804 & -5.639 & 0.000 & -11.755 & 0.000 \\
Income & -1.236 & 0.897 & -1.236 & 0.897 & -6.703 & 0.000 & -8.594 & 0.000 \\
\hline Wealth & -2.671 & 0.251 & -2.671 & 0.251 & -11.442 & 0.000 & -11.442 & 0.000 \\
Sales & -2.650 & 0.260 & -2.102 & 0.537 & -7.724 & 0.000 & -9.683 & 0.000 \\
Import & -2.700 & 0.239 & -2.700 & 0.239 & -8.303 & 0.000 & -8.303 & 0.000 \\
\hline Total & \multicolumn{1}{|c|}{} & & & & & & \\
\hline
\end{tabular}

\begin{tabular}{|c|c|c|c|c|c|c|c|}
\hline \multicolumn{8}{|c|}{ PP Unit Root Test Results } \\
\hline Test Specification & & $(\ln )$ GDP & (In)/Incom & In)Wealth & (In)Sales & (In)/mport & $(\ln ) T T R$ \\
\hline \multirow{2}{*}{$\begin{array}{c}\text { With Constant and Trend } \\
\text { At Level }\end{array}$} & t-Stat & 5.509 & 4.785 & 4.844 & 4.908 & 6.281 & 5.330 \\
\hline & Prob. & 1.000 & 1.000 & 1.000 & 1.000 & 1.000 & 1.0 \\
\hline \multirow{2}{*}{$\begin{array}{c}\text { Without Constant \& Trend } \\
\text { At First Difference }\end{array}$} & t-Stat & -2.631 & -3.905 & -7.595 & -3.194 & -5.183 & -2.559 \\
\hline & Prob. & 0.009 & 0.000 & 0.000 & 0.002 & 0.000 & 0.011 \\
\hline
\end{tabular}

As seen above, all variables are found to be first order integrated, which implies that equation

Error! Reference source not found. must be estimated through a cointegrating regression. In the presence of unit root, if there is cointegration among the series, it possible to derive short and longrun tax elasticity figures. Considering this, the autoregressive distributed lag (ARDL) method developed by Pesaran and Shin (1998) and Pesaran, Shin, and Smith (2001) is employed for the regression.

The ARDL is a standard OLS based regression model which is estimated in three steps: first, an ordinary OLS model at level is conducted by incorporating an autoregressive term (it could be more than one lag) along with lags of independent variables into the right-hand side. Then, the presence of cointegration among the series is investigated by the bound test approach. Accordingly, coefficients of the lag level variables are restricted to be zero, and their significance is tested with the F-test. ${ }^{4}$ If

\footnotetext{
${ }^{4}$ Upper and lower bounds of the F-test is provided in Pesaran (2001). Later, a study by Narayan and Narayan (2005) generated upper and lower bounds of the F-test for small sample sizes. If
} 
the parameter estimates of the autoregressive term at level and distributed lags of independent variables at level are found to be zero, this is interpreted as absence of a long-run (cointegrating) relationship among the variables. If the parameter estimates are found to be different than zero, then ARDL model is estimated with the first-differenced series and with the inclusion of an error-correction parameter similar to the Engle and Granger (1987) method. The number of lags for the model at level and at first-difference is often automatically selected by the software, based on the Akaike or Schwarz information criteria. SIC often suggests a more parsimonious model, which implies a smaller number of autoregressive and distributed lag terms in the model. At this point, the researcher should select the correct lag level by considering standard OLS assumptions such as achieving absence of autocorrelation and heteroscedasticity. Lastly, the long-run parameters are simply obtained by running an OLS model at level only with independent variables in the right-hand side by excluding their lags and the autoregressive term. To note, both short and long-run forms of the ARDL model can be estimated with a trend. Deterministic variables (e.g. dummies which are not required to be differenced in error-correction model) in the error correction form are also allowed in the model.

It should be noted that ARDL does not tackle the endogeneity problem. As stated above, previous studies on Turkey found a bilateral Granger causality between taxes and GDP. In this case, ideally the model should be estimated with a vector error correction model (VECM) in which all variables are endogenously treated. Also, deterministic variables representing tax regime shifts (i.e. additive outliers) should also be considered, otherwise the number of cointegrating relationships may be overestimated (i.e. spurious long-run relationships are accepted), as shown in Leybourne and Newbold (2003). In this way, it will be possible to obtain short and long-run tax elasticity figures under different tax regimes. Nonetheless, this type of estimation is currently left for future research. Instead

the calculated F-test from the hypothesis testing falls above the upper bound than presence of the cointegration is accepted. If the F-test result lies between the upper and lower bounds, presence of cointegration is inconclusive. Lastly, if the F-test falls below the lower bound, absence of cointegration is accepted. 
of a VECM, the long-run parameter estimates (i.e. long-run tax elasticity figures) immune to endogeneity as well as to autocorrelation and heteroscedasticity problems, see Phillips (1995), is obtained by employing fully modified OLS (FMOLS). The FMOLS estimates are reported in Table 2, along with the ARDL results as a robustness check. Both models are estimated with a trend term - for trend parameter estimates see Table 3. For the ARDL method, lags are automatically selected by EViews (v. 9.5) according to AIC, and reported standard errors are heteroscedasticity and autocorrelation consistent (HAC).

\subsubsection{Results: Tax Elasticities}

An elasticity figure greater than unity is taken to be elastic while if it lies between zero and unity it is taken to be inelastic. Accordingly, income tax is the least elastic, with the smallest elasticity figures both in the short- and the long-run. A possible explanation is that roughly 65 percent of the income tax is withheld, as stated in Revenue Administration 2017 Annual Report (p. 152, Table 7), i.e. deducted at source, and these taxpayers are regular employees working on a payroll basis with an annual contract. They may not be affected by an income shock immediately as their annual income is already determined at beginning of their contract. Also, the time lag between realisation and collection of the income and corporate taxes can explain the significantly lower short-run income tax elasticity figure. This argument is supported by the error-correction estimate - the income tax has the smallest adjustment parameter, which implies that tax the revenue restores back to the equilibrium in case of an income shock approximately in 14 months.

Table 2: $\beta$ Parameter Estimates (Tax Elasticities)

\begin{tabular}{|c|c|c|c|c|}
\hline \multicolumn{5}{|c|}{ Tax Elasticity } \\
\hline Revenue & Long-run (ARDL) & Long-run (FMOLS) & Short-run (ARDL) & Error-Correction (ARDL) \\
\hline Income Tax & $0.80^{* * *}$ & $0.83^{* * *}$ & $0.33^{* * *}$ & $-0.83^{* * *}$ \\
Wealth Tax & $1.14^{* * *}$ & $1.16^{* * *}$ & $1.53^{* * *}$ & $-1.27^{* * *}$ \\
Sales Tax & $1.10^{* * *}$ & $1.05^{* * *}$ & $0.60^{* * *}$ & $-1.66^{* * *}$ \\
Import Tax & $0.98^{* * *}$ & $0.93^{* * *}$ & $0.55^{* * *}$ & $-1.05^{* * *}$ \\
Total Tax & $0.97^{* * *}$ & $0.98^{* * *}$ & $0.76^{* * *}$ & $-1.22^{* * *}$ \\
\hline
\end{tabular}


$* p>0.1 * * p>0.05 * * * p>0.01$

Excluding wealth tax, all the short-run tax elasticities are smaller than the long-run ones. It appears that in case of a negative income shock, wealth ownership falls, and so does the wealth tax revenue for government. However, in the long-run taxpayers can restore their wealth and this can make its revenue less income elastic. Hence, short-run wealth tax elasticity is found to be greater than its long-run figure.

Besides, when the study by Creedy and Gemmell (2004) discusses elasticity of consumption taxes, it emphasizes how the income elasticity of demand and marginal propensity to consume (i.e. pure income effect, PIE) can affect the elasticity of a consumption tax. Accordingly, in Chapter 4, shortrun PIE, and budget elasticity of demand (BED) for transport (which includes vehicle consumption) are found to be among the largest figures, implying that vehicle consumption is a luxury and in case of a real income change consumers prefer to spend extra budget on vehicle consumption rather than other commodities. In this regard, it is understandable that in case of an income shock vehicle demand will be affected relatively more strongly than non-luxury goods, which will also affect the motor vehicle ownership tax and its elasticity. It is consistent to find the wealth tax more elastic in the short-run than in the long-run given that over 90 percent of the wealth tax revenue currently comes from motor vehicle ownership tax, as stated by 2018b).

Parameter estimates regarding the long-run trend are reported in Table 3 below.

Table 3: Trend Parameter Estimates

\begin{tabular}{|c|c|c|c|c|c|}
\hline \multicolumn{7}{|c|}{ Trend Parameter Estimates } \\
\hline \multirow{2}{*}{ Trend $_{\text {ARDL }}$} & Income & Wealth & Sales & Import & Total \\
\cline { 2 - 6 } & $0.034 * * *$ & $-0.090^{* * *}$ & -0.008 & 0.011 & 0.007 \\
\hline Trend $_{\mathrm{FMOLS}}$ & $0.044^{* * *}$ & $-0.073 * * *$ & $-0.010^{* *}$ & 0.007 & 0.005 \\
\hline
\end{tabular}

$* p>0.1 * * p>0.05 * * * p>0.01$

Two models report similar and significant results for long-run trend of the income and wealth tax revenue. Accordingly, the trend which is seen to have a negligible downward effect for the sales 
tax revenue, reported to be significant for FMOLS estimation but insignificant for the ARDL. Additionally, the trend has been upward and significant for the income tax whereas it is found to be negative and significant for the wealth tax.

The income tax discussed here consists of income tax collected from individuals and corporates. According to OECD (2017), average personal income tax rate has lied between 15.50 and 11.75 percent between 2000 and 2016. The average tax rate on corporates has been between 32 percent and 20 percent in the same period. Tax rate figures address that there is not a dramatic tax rate increase in the last seventeen years, which could lead to a increasing trend for the income tax revenue, but instead of that both tax rates decreased. In this case, the upward trend in the income tax is likely to be linked to increasing number of taxpayers for the personal income tax (PIT). Figure 8 shows that PIT revenue, which is mostly (65 percent) paid on withholding tax basis as previously mentioned, had been twice as large as the CIT revenue at least for a ten-year period.

Figure 8: Decomposition of the Income Tax, 2006 - 2016

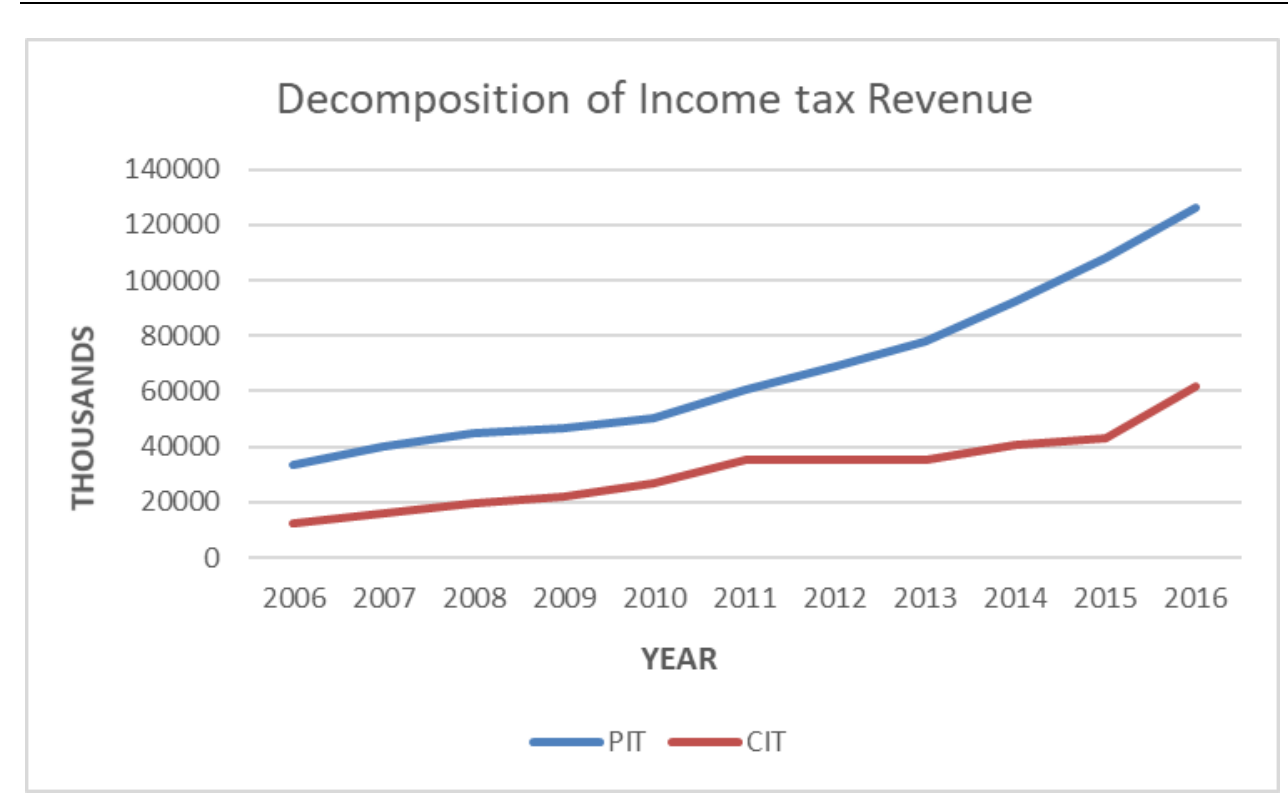

Data from General Directorate of Budget and Fiscal Control, Budget Figures and Budget Realization, Budget Figures since 1924. Last Access: 23.11.2017. 
Furthermore, Bühn and Schneider (2012) reports that for Turkey, the size of tax evasion has decreased from 10.8 percent to 7.8 percent of GDP, between 1999 and 2010 . The same study also states that the average relative impact of the income tax on the shadow economy in Turkey is 4.9 percent, which is one of the lowest among the 38 OECD countries, while the average relative impact of the indirect taxes on the shadow economy has been 31.4 percent. These figures can be interpreted as that the income tax evasion is less likely to occur due to collecting it through withholding tax. Changing labour market composition can somewhat shed light on this issue. Figure 9 shows that regular employment has remarkably increased in the last seventeen years. The regular employees pay withholding tax, i.e. employers deduct the income tax and pay the net salary. Increasing number of taxpayers who are paying an income tax on withholding tax basis, which has a lower chance of tax evasion, see Bühn and Schneider (2012), can shed some light on the increasing trend of income tax. In other words, the number of taxpayers who pay an income tax with a low chance of tax evasion has increased over time, and this can be one of the reasons why we observe an upward trend for the income tax revenue.

Figure 9: Decomposition of Employment, 2000 - 2017

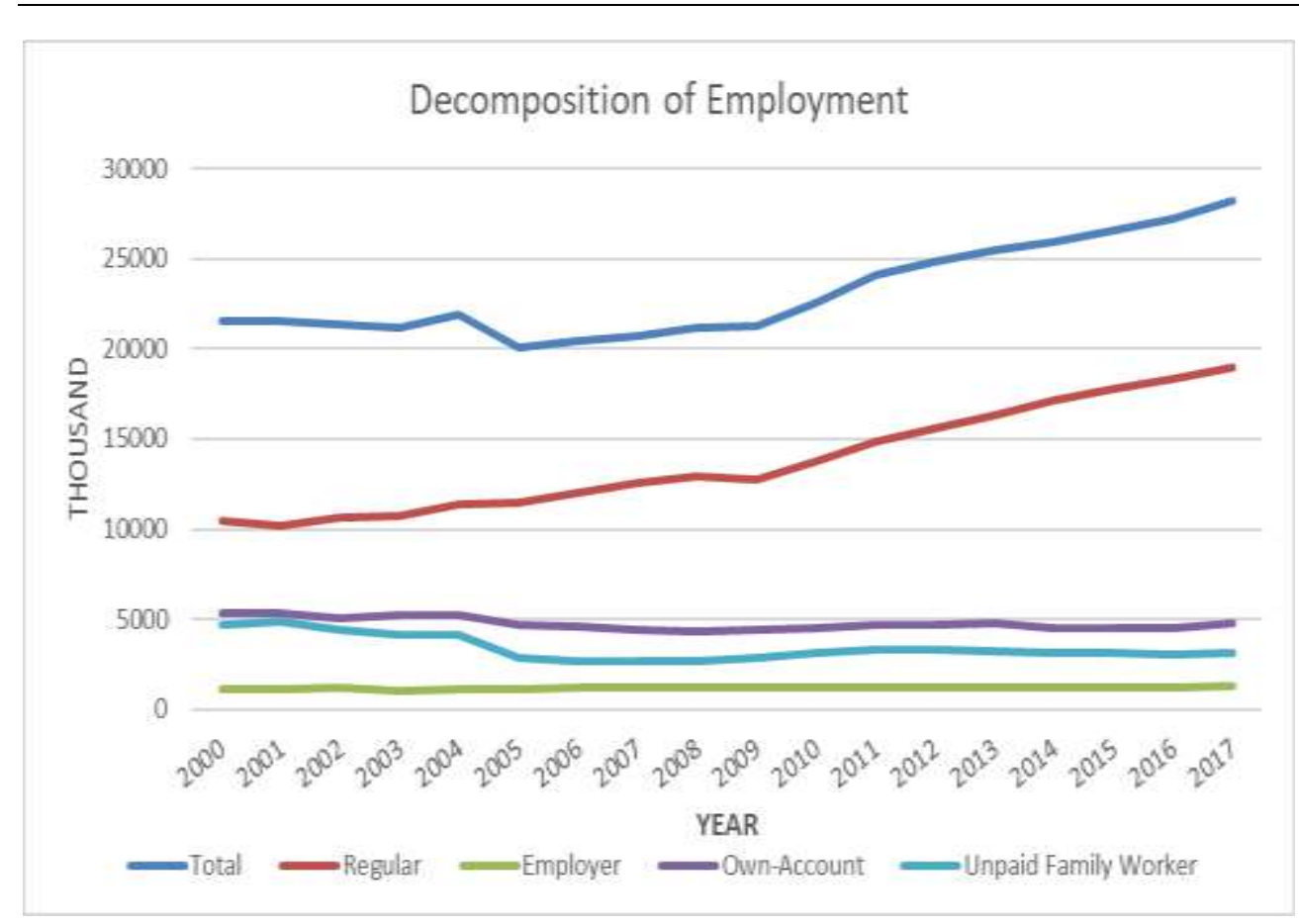


The downward trend for the wealth tax can be associated with increasing reluctance of the government to levy tax on wealth which is evident as seen in Figure 2, which is linked to the aforesaid economic liberalisation. The links between wealth tax revenue and liberalisation are further investigated through the tax progressivity figures presented below.

\subsubsection{Tax progressivity}

So far tax progressivity figures for the Turkish economy are provided in the studies by Albayrak (2010), and Albayrak (2011). These studies investigated the role of different taxes on income inequality in Turkey. In this regard, Albayrak (2010) calculated pre and post-tax Lorenz dominance curves for households, on the basis of 2003 HBS data. It is shown that that indirect taxes (the study separately evaluated sales and import taxes) have different effects on inequality according to the welfare indicator chosen: indirect taxes improve expenditure inequality but distort income inequality. Albayrak (2011) used 2004 and 2009 HBS data and stated that the tax cuts in 2009 increased the distortionary effects of indirect taxes on the income distribution. In this regard, although these studies capture tax incidence on single household by taking into account household characteristics, they can allow the reader to compare only one-term elasticity figures with each other, and merely for post2000 period. In other words, it is not possible to observe the evolution of tax progressivity.

However, the elasticity figures discussed above are closely related to tax progressivity, as discussed in Kakwani (1977) and can be employed to enhance the analysis. As he described, tax progressivity shows the deviation from proportionality. In the case of a proportional tax (i.e. tax rate is fixed) the tax elasticity is always equal to one, and this makes it possible to derive a tax progressivity index which measures deviation from the unit tax elasticity for a given tax. In this frame, a more recent study by Kakinaka and Pereira (2006) presented a progressivity index derived from tax elasticity figures. The method departs from the traditional Lorenz curve approach adopted by Albayrak (2010), and Albayrak (2011). Accordingly, the study proposes a method which can be estimated with time- 
series data: tax revenues and the GDP. Although it does not deliver household-specific distributional impact, it allows researcher to derive the evolution of tax progressivity for different types of taxes over time, with remarkably less data demanding calculations. The formula to derive tax progressivity index used by Kakinaka and Pereira (2006) is as given below:

$$
\gamma_{t} \equiv \frac{\hat{\sigma}_{T, t}}{\hat{\sigma}_{Y, t}}
$$

In (1.3), $\hat{\sigma}_{T, t}$ is the proportional standard deviation of the specific tax revenue, which implies that its standard deviation is divided into its mean for period $(t)$, and $\hat{\sigma}_{Y, t}$ is the proportional standard deviation of the national income (GDP), which implies that the standard deviation of the GDP is divided into its mean for period $(t)$. Hence, the progressivity index $\left(\nu_{t}\right)$ measures the responsiveness of the tax revenue volatility to the volatility of the GDP. Given this, $\gamma_{t}>1$ implies that the tax is progressive, $\gamma_{t}<1$ is regressive and if $y_{t}=1$ the tax is proportional.

Based on this formula, progressivity indices for income, wealth, sales, import and general tax revenue are calculated for three periods. These periods are, 1924 to 1959, then 1960 to 1989 and lastly 1990 to 2016 . The first period starts with foundation of the Republic until the import substitution regime is adopted in 1960 . The second term ends in 1989, when the economy was fully liberalised by adopting free exchange regime as stated in Önis (2006). The final period is from 1990 to 2016, a period which witnessed five economic crises. The study by Kakinaka and Pereira (2006) calculated the formula by detrending series with a Hodrick-Prescott filter. Considering that long-run trend parameters are found to be significant for three taxes (income, wealth, and sales) at least for one estimation, this research reported tax progressivity indices with filtered series along with the unfiltered series - see appendix. The Hodrick-Prescott filter is imposed on annual series by setting the smoothing parameter at 19, as suggested by Yuksel et al. (2011). The results are reported in Table 4 below. 
Table 4: Tax Progressivity Indices

\begin{tabular}{|c|c|c|c|c|c|}
\hline \multicolumn{7}{|c|}{$\gamma$ with Filtered Series } \\
\hline Term & Income & Wealth & Sales & Import & Total Tax \\
\hline $1924-1959$ & 1.087 & 2.011 & 0.300 & 0.346 & 3.701 \\
$1960-1989$ & 1.026 & 0.543 & 0.631 & 0.222 & 0.969 \\
$1990-2016$ & 0.126 & 0.091 & 0.881 & 0.409 & 0.243 \\
\hline \multicolumn{5}{|c|}{$\gamma$ with Unfiltered Series } \\
\hline Term & Income & Wealth & Sales & Import & Total Tax \\
\hline 1924 - 1959 & 2.526 & 1.449 & 1.733 & 1.855 & 1.470 \\
$1960-1989$ & 1.446 & 1.875 & 1.311 & 1.340 & 1.249 \\
$1990-2016$ & 1.161 & 1.647 & 1.269 & 1.302 & 1.178 \\
\hline
\end{tabular}

The first remarkable finding is that the income tax has continuously become less progressive: figures have decreased for filtered and unfiltered series for all periods. However, the filtered series suggests that once the trend effect is eliminated the income tax becomes regressive (the figures are smaller than unity). This pattern matches with the progressivity of the total tax revenue, which has continuously become less progressive for unfiltered series and transformed into regressive from progressive, according to the filtered series. The tax progressivity indices for these taxes are consistent with the tax elasticity figures presented in Table 2. The elasticity figures of these taxes are both inelastic and the degree of progressivity is decreasing, and this is consistent with the evidence of Kakinaka and Pereira (2006), which predict inelastic taxes to be regressive. Further research is needed to investigate (such as Granger-causality test) the role of decreasing progressivity of income tax on decreasing progressivity of total tax revenue.

As to the wealth, for the filtered series there is a continuous decline, and, according to the unfiltered series, for 1960-1989 term the wealth tax became more progressive compared to the previous term. The significant downward trend of the wealth tax and decreasing progressivity of it according to the filtered series can be correlated, i.e. it is likely that as wealth tax revenue decreases, its progressivity also decreases. This issue also needs to be further investigated using Granger causality test. 
As to the sales tax, the calculation based on the filtered series reports that sales tax is a regressive tax, but its relatively less regressive from 1990 onward. As to the figures based on unfiltered series, it has clearly become less progressive. The progressivity indices for the sales tax also tallies with the tax elasticity figures. Long-run ARDL and FMOLS models estimates report an elastic sales tax revenue with respect to income, but in the short-run the sales tax revenue becomes inelastic. The short-run ARDL model is estimated with the first-differenced series, and first differencing is a method of detrending series working similarly to the HP filter. In this regard, inelastic sales tax revenue and regressive sales tax revenue reported by the filtered series are consistent.

To summarise, it is seen that the tax burden is rising, and the Turkish economy becomes more similar to the developed members of the OECD. It was also shown that the dominance of the indirect tax revenue on total tax revenue is not a phenomenon which came to the scene with the liberalisation of the 1980s, but it is a feature of the Turkish tax system from the foundation of the Republic. However, macroeconomic policies affected the composition of the indirect taxes: once Turkey left the import-substitution policy and adopted liberal international trade regime; the import tax revenue lost its power on indirect tax revenues. The last part of the section 1.2 provided tax elasticity and progressivity estimates calculated with time-series data. As expected, there is a relationship between tax elasticity and progressivity: more elastic taxes are in tandem with greater progressivity. In this regard, overall, the Turkish tax system is found to be regressive according to the filtered series or becoming less progressive based on unfiltered series.

\subsection{TAXES and CONSUMPTION DEMAND PATTERNS}

As shown in Table 2, in the case of an income shock the sales tax is the fastest when restoring back to the equilibrium compared to the other tax types. In other words, the tax revenue fluctuations (in the case of a negative income shock this will be a revenue loss) is restored back to its normal values within 6 months ( 1 year/1.66), whereas this is more than a year for the income tax $(1 / 0.83)$. This indicates an efficiency gain (i.e. limited tax revenue loss during a negative income shock due to high 
share of sales tax in total tax revenue) from the current tax revenue composition for the government, although the indirect taxes are shown to be regressive by Albayrak (2010).

During the 2009 economic crisis, the Turkish government implemented a series of tax cuts as previously discussed in the second chapter. Durables, transport and culture commodity groups were affected from the tax cuts. This section provides a brief analysis for the tax cuts imposed in 2009 to reduce the effect of the economic crisis. The durables were exempt from the dynamic AIDS estimation in error correction form, but the short-run own-price elasticity figures (Marshallian, uncompensated) were derived for transport and culture to capture the immediate response of the consumers during the 2009 economic crisis. For this reason, the discussion on tax cut presented below is based on these two commodity groups.

Tax changes and their effects on household welfare demand has been one of the areas which benefits from elasticity figures obtained from a demand system estimation. For example, Decoster and Schokkaert (1990) evaluated potential welfare effects of an indirect tax regime change in Belgium by estimating AIDS, Rotterdam and Central Bureau of Statistics (CBS) - a demand system developed by Keller and Van Driel (1985) - and LES models. The study had advantages while estimating these systems, since it can access data from national accounts and household data from Belgian consumer expenditure survey. The study aimed to compare the models rather than conducting a welfare analysis. The study found that in case of a tax reform analysis, elasticities obtained from different demand estimations did not show remarkable differences in results. Later, a study by Dargay and Goodwin (1995) calculated transport demand elasticities and applied the standard consumer surplus formula (the area under the demand curve between the highest price that consumer is willing to pay and equilibrium price) to test the effects of rising costs. A study Banks, Blundell, and Lewbel (1996) estimated a QUAIDS model for the UK economy to obtain Marshallian own-price elasticities, which are used to analyse the impact of a 17.5 percent tax change for clothing items. By applying a utility function, the effect of the price changes on consumer's utility is discussed. 
Kaplanoglou and Newbery (2003) studied the effects of an indirect tax reform on household consumption in Greece. The study investigates possible outcomes, considering the case that Greece were to adopt the UK indirect tax system, using HBS data. The study differs from other studies as it also provided Lorenz curves for the post-reform income distribution. Later, this study was replicated for the Turkish economy by Ardic, Erus, and Soydan (2010), but the study does not provide the discussions via Lorenz curve. Accordingly, if there is no concern of inequality, housing, tobacco and alcohol, and then culture expenditures arose to be the commodity groups which can maximise government tax revenue following a tax reform for the Turkish economy.

The study by West and Williams (2004) estimated an AIDS model by using HBS data and investigated progressivity of the gasoline tax and its effect on consumer surplus. The study found that an increase in the gasoline tax would be regressive. A study by Leyaro, Morrissey, and Owens (2010) estimated AIDS model for Tanzanian households by using HBS data, and analysed the welfare effects of the VAT and tariff changes regarding food consumption. In the study, it is concluded that an explicit tax incidence was not observed on the prices following the tax reform. The effects of the tariff reduction on the price level were simulated, and according to the simulation results it was revealed that the urban poor could benefit more than the rural poor as from the decrease in tariffs on food. A study by Ahmed, Jalil, and Idrees (2013) calculated elasticities through an AIDS model using HBS data from Pakistan. The study estimated two AIDS models: i) a benchmark model with current total expenditures for 6 commodities and current price levels ii) another model with prices and total expenditure figures obtained following a uniform indirect tax reform. The change in household welfare was derived by comparing these two models. The study shows that replacing the existing tax system with a uniform indirect tax regime would generate a substantial welfare increase for households. A common characteristic of these works is that they try to explain the change in consumer welfare by measuring the pre- and post-policy change in utility levels. In other words, they calculate equivalent and compensating variation. 
Neoclassical microeconomic theory states that the consumer achieves equilibrium once the utility (satisfaction level) is maximised with the given income. The income, here, forms budget constraint. Utility maximisation can be achieved with several different options of commodity combinations. Therefore, there is no unique set of commodities which maximises the utility of the consumer but are several of them. The set of commodity combinations are known as indifference curves. However, the equilibrium is unique: once one of the preferred commodity sets is obtained with the given income level, the equilibrium is achieved. If the consumer goes on the consumption, utility maximisation is maintained, and this makes utility continuous. Nonetheless, there is no free lunch, and all options, i.e. choices, are subject to a price. Once the price(s) of the commodities or the consumer's income change, the consumer is expected move to a new indifference curve. Comparing the initial indifference curve to the present one provides substantial information about the welfare impacts of price and income changes. Nonetheless, utility is an abstract concept to measure, therefore two money-based concepts are conventionally used in order to measure changes in the consumer's utility. The first concept is price compensating variation (CV) and the second one is income equivalence variation (EV). These two concepts allow the consumer to observe changes in her utility level in monetary terms. However, in order to be able to calculate EV and CV, an arbitrary utility function must be selected. EV and CV is derived from ordinal utility functions (e.g. Cobb-Douglas or Constant Elasticity of Substitution - CES), thus it is not possible to observe change in consumer's utility in numbers but in direction (i.e. increase, decrease or no change in the utility levels).

Instead of following the EV and CV route, which needs to set an arbitrary utility function, we measure change in consumer welfare by looking at consumer surplus, a simpler method discussed in Araar and Verme (2016). For instance, a study by Hausman and Ros (2013) estimates a log-log demand system for the Mexican economy to calculate the consumer surplus occurring as a result of lower prices of telecommunication for Mexican households. The study reveals that Mexican consumers have greater surplus than their counterparts in other countries due to lower telecommunication costs. The consumer surplus formula calculated by Hausman and Ros (2013) is more convenient for this research 
compared to studies mentioned earlier, as it does not require information on household income or ranking, the study uses the formula for calculation of the consumer surplus in percentages given below:

$$
\frac{(\triangle C S)_{G o o d ~ A}}{\text { Current Total Expenditure on Good A }}=\underbrace{\frac{1}{1-P E D_{A}}\left[\left(\frac{P_{2}}{P_{1}}\right)^{1-P E D_{A}}-1\right]}_{\text {\%change in consumer surplus }}
$$

and $P E D_{A}=\left|P E D_{A}\right|$

In (1.4), $\Delta C S$ is the change in the consumer surplus, $P_{1}$ is the current price and $P_{2}$ is the expected price as a result of tax policy change. By employing this formula and benefitting from short-run PED figures estimated in Ceylan (2018) , the change in consumer surplus is calculated for transport and culture, the two commodity groups which were subject to the tax cuts imposed during 6 months in 2009 economic crisis - see Chapter 2 in Ceylan (2018) for the discussion on tax cuts.

Ardic, Erus, and Soydan (2010) report (p. 15) an average tax rate of 41.73 percent for transport, which has the heaviest tax burden. Predicted budget shares were found to be roughly 6 percent for culture and 16 percent for transport. In other words, these two commodity groups account for almost one quarter of consumer's budget. On the other hand, these commodity groups are mainly consumed by the high-income groups. 
Transport

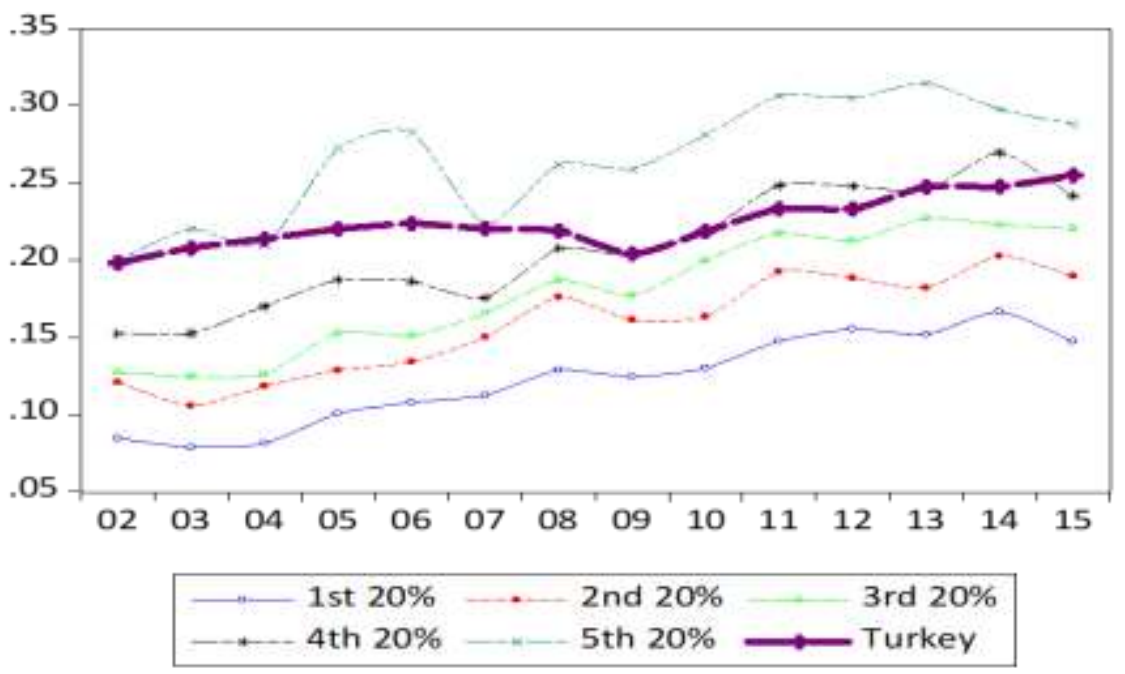

Culture

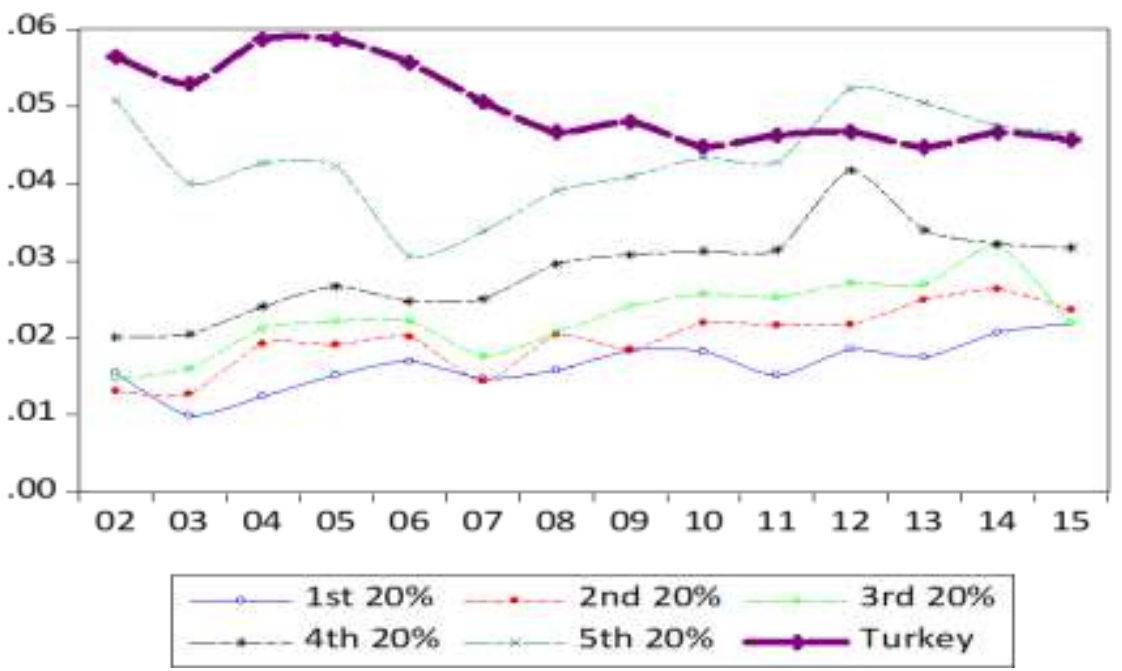

Quintile Data from TURKSTAT HBS from 2002 to 2016. Last Access: 18.01.2018.

Figure 10 above shows to budget shares devoted to culture and transport by per each income quintiles (from national accounts, the main dataset used in this thesis). As seen, a comparison between the HBS data and data from the national accounts reflects the gap, Turkey's average budget shares for transport and culture are closer to high-income groups consumption. Nevertheless, there is a convergence between Turkey's average budget share and the budget shares of the first, second and third income quintiles for two commodities. 
The short-run change in the consumer surplus calculated according to the

Error! Reference source not found. , are presented in Table 5 . The new prices $\left(P_{2}\right.$, average price change in second and third quarters) obtained from Türkan (2009) which provided post-tax cut prices quarterly. As seen in Table 5, tax cuts increased the consumer surplus for transport and culture by around 7 percent.

Table 5: Consumer Surplus for Transport and Culture, 2009 Second Quarters

\begin{tabular}{|c|c|c|c|c|c|}
\hline \multicolumn{7}{|c|}{ Consumer Surplus } \\
\hline & Total Expenditure & $\Delta$ P & PED & $\Delta$ CS & $\Delta$ CS \\
\hline Transport & 3094142 & $7.52 \%$ & -2.05 & $6.98 \%$ & 216019 \\
Culture & 895885 & $7.89 \%$ & -1.92 & $7.33 \%$ & 65713 \\
\hline
\end{tabular}

Total Expenditure and $\triangle C S:$ Thousands TRY.

The positive change in consumer surplus can be interpreted as an increase in real income. As expected, the percentage change in consumer surplus is less than the percentage change in price since these goods are luxuries, i.e. quantity demand increases faster than the decrease in the price, and this leads to a smaller increase in consumer surplus in luxuries compared to normal goods. On the other hand, the consumers benefit from the consumer surplus according to their share from the consumption of the good.

Table 6: Shares of Quintiles in Transport and Culture Expenditure, 2009

\begin{tabular}{|c|c|c|c|c|c|}
\hline \multicolumn{5}{|c|}{ Shares of Quintiles Ordered by Income in Expenditure Types } \\
\hline 2009 & 1st 20\% & 2nd 20\% & 3rd 20\% & 4th 20\% & 5th 20\% \\
\hline Transport & 5.0 & 9.1 & 14.9 & 23.5 & 47.5 \\
Culture & 5.5 & 8.4 & 15.3 & 24.2 & 46.6 \\
\hline
\end{tabular}

Quintile Data from TURKSTAT HBS 2009. Last Access: 18.01.2018.

According to Table 6, the largest share from the transport and culture consumption is taken by the top quintile - it is seen that they take almost half of consumer surplus. Once the fourth and 
fifth quintiles are considered together, it is seen that only 30 percent of the consumer surplus remains for the bottom three quintiles. This result is consistent with the findings in Albayrak (2011), which stated that tax cuts of 2009 was regressive. It is shown here once again; the consumer surplus generated a real income transfer for the top two income quintiles more than twice of that generated for the bottom three income quintiles.

\subsection{CONCLUSION}

This study provides an extensive analysis of Turkish tax system in refer to its historical evolution and an empirical approach elaborated to understand how this historical evolution affected tax progressivity. It contributes to the existing literature by revealing that indirect taxes which consist of sales taxes collected from consumption and import have always had the largest share in the total tax revenue. In this respect, contrary to what other studies say, the indirect tax revenue did not increase its dominance in total tax revenue due to liberalisation, but the indirect tax revenue composition through liberalisation.

Another important contribution of the study is calculating the tax elasticities and deriving the tax progressivity figures from them. The estimate of the tax elasticities is calculated by employing ARDL and FMOLS models. The ARDL model is estimated to be able to derive short and long-run elasticity figures. However, there can be a bidirectional relationship between GDP and tax revenues, and this may lead to endogeneity problem which may raise issues on robustness of the ARDL model. For this reason, an FMOLS model is also estimated. According to these models, income and import taxes are shown to be inelastic whereas sales and wealth taxes are found to be elastic. Nonetheless, sum of the income and import tax revenues correspond to a large share of total tax revenue, and this generate a less progressive tax system.

Considering points above, tax progressivity figures are obtained for three different periods for which significant differences in tax policies were experienced. The progressivity figures are calculated for filtered (HP filter was imposed) and non-filtered series due to robustness concerns since it is shown 
that HP filter may produce over-smoothed series - see Ravn and Uhlig (2001). Results show that Turkish tax system has become less progressive over time and all taxes are found to be regressive from 1990 onward. It is also seen that tax cuts implemented during 2009 economic crisis were regressive.

Nonetheless, the analysis presented in this paper can be further improved by taking into two issues. The first issue is the elasticity figures are derived for $1924-2016$ period and did not take into account structural changes affected the policy. The ARDL and FMOLS models can be estimated with dummies corresponding to the policy shifts, and figures obtained from these estimations can be used to calculate tax progressivity figures.

The second issue is again on elasticity figures. These figures are calculated by using the GDP as the tax base. Another method to calculate this could be for example calculating import tax elasticity by using import value (can be found in national income data). However, a tax base for wealth tax and income can be problematic to obtain due to absence of the data. The tax analysis starts with 1924 and it is not possible obtain household revenue statistic which starts in the same year of the analysis. Although, for the sales tax domestic final consumption derived from GDP data can be used as the tax base, it is again not possible to obtain a tax base to calculate wealth tax elasticity. Considering these concerns, the study can be limited to $2003-2017$ period for which it is possible to derive income tax base and wealth tax base by using the household budget surveys. The analysis is still compelling, as seen in Figure 11, GDP and tax revenues mirror each other, and this makes GDP a valid proxy for being used as the tax base in the analysis.

\section{REFERENCES}

2017. Budget Figures and Budget Realizations : Budget Figures Since 1924. General Directorate of Budget and Fiscal Control 2017 [cited 23.11.2017 2017]. Available from http://www.bumko.gov.tr/EN,2680/budget-figures-since-1924.html.

2018a. Annual Report 2017. Ankara: Revenue Administration.

2018b. General Budget Statistics. General Directorate of Public Accountants Ministry of Finance.

Açikgöz, Şenay. 2008. "Türkiye'de Vergi Gelirleri, Vergi Yapısı ve İktisadi Büyüme İlişkisi: 1968-2006." Ekonomik Yaklasim no. 19 (68):91-113. 
Ahmed, Eatzat, Abdul Jalil, and Muhammad Idrees. 2013. "Almost Ideal Demand System and Uniform Taxation in Pakistan: Econometric Evidences for Consumer Goods in Pakistan, 1984-2008." Applied Econometrics and International Development no. 13 (2):207-216.

Albayrak, Özlem. 2010. "Redistributive Effects of Indirect Taxes in Turkey 2003." Ankyra: Ankara Üniversitesi Sosyal Bilimler Enstitüsü Dergisi no. 2 (1):123 - 161.

Albayrak, Özlem. 2011. "Finansal Krizde Uygulanan Vergi Politikalarının Gelir Dağilimi Etkileri: 20042009." Ankara Üniversitesi SBF Dergisi no. 66 (02):001-034.

Altug, Sumru, Alpay Filiztekin, and Şevket Pamuk. 2008. "Sources of long-term economic growth for Turkey, 1880-2005." European Review of Economic History no. 12 (3):393-430. doi: $10.1017 /$ S1361491608002293.

Antonucci, Daniele, and Stefano Manzocchi. 2006. "Does Turkey have a special trade relation with the EU?: A gravity model approach." Economic Systems no. 30 (2):157-169. doi: https://doi.org/10.1016/j.ecosys.2005.10.003.

Araar, Abdelkrim, and Paolo Verme. 2016. Prices and welfare. ECINEQ, Society for the Study of Economic Inequality.

Ardic, Oya Pinar, Burcay Erus, and Gurcan Soydan. 2010. "An evaluation of indirect taxes in Turkey." Economics Bulletin no. 30 (4):2787-2801.

Arıkboğa, Aysel. 2011. "Maliye Politikalarında 1980 Sonrasında Yaşanan Değişim: Mali Disiplin ve Mali Kural Uygulamaları." Sosyal Bilimler Dergisi no. 2:13-25.

Arıkboğa, Aysel. 2015. "Financial Liberalisation and Composition of Tax Revenues in Turkey." Calisma ve Toplum no. 45 (2).

Atkinson, Anthony B. 1970. "On the measurement of inequality." Journal of economic theory no. 2 (3):244-263.

Banks, James, Richard Blundell, and Arthur Lewbel. 1996. "Tax reform and welfare measurement: do we need demand system estimation?" The Economic Journal:1227-1241.

Baysan, Tercan, and Charles Blitzer. 1990. "Turkey's Trade Liberalization in the 1980s and Prospects for its Sustainability." In The political economy of Turkey, 9-36. Springer.

Birtek, Faruk. 1985. "The Rise and Fall of Etatism in Turkey, 1932-1950: The Uncertain Road in the Restructuring of a Semiperipheral Economy." Review (Fernand Braudel Center) no. 8 (3):407438.

Boratav, Korkut. 2008. Türkiye iktisat tarihi, 1908-2007. Ankara: İmge kitabevi.

Boratav, Korkut, and Erinc Yeldan. 2006. "Turkey, 1980-2000: Financial Liberalization, Macroeconomic (In) Stability, and Patterns of Distribution." External Liberalization in Asia, Post-Socialist Europe, and Brazil:417.

Bühn, Andreas, and Friedrich Schneider. 2012. Size and Development of Tax Evasion in 38 OECD Countries: What do we (not) know? : CESifo Group Munich.

Ceylan, Fethiye Burcu. 2018. Essays on Consumption Demand in Turkey (Unpublished PhD Thesis), School of International Development, University of East Anglia, Norwich, UK.

Çiçek, Deniz, and Ceyhun Elgin. 2011. "Not-quite-great depressions of Turkey: A quantitative analysis of economic growth over 1968-2004." Economic Modelling no. 28 (6):2691-2700.

Creedy, John, and Norman Gemmell. 2004. "The income elasticity of tax revenue: Estimates for income and consumption taxes in the United Kingdom." Fiscal Studies no. 25 (1):55-77.

Creedy, John, and Norman Gemmell. 2008. "Corporation tax buoyancy and revenue elasticity in the UK." Economic Modelling no. 25 (1):24-37.

Dargay, Joyce M, and PB Goodwin. 1995. "Evaluation of consumer surplus with dynamic demand." Journal of Transport Economics and Policy:179-193.

Decoster, Andre, and Erik Schokkaert. 1990. "Tax reform results with different demand systems." Journal of Public Economics no. 41 (3):277-296.

Demir, Firat. 2004. "A Failure Story: Politics and Financial Liberalization in Turkey, Revisiting the Revolving Door Hypothesis." World Development no. 32 (5):851-869. doi: https://doi.org/10.1016/j.worlddev.2003.11.007. 
Dervis, Kemal, and Sherman Robinson. 1982. "A general equilibrium analysis of the causes of a foreign exchange crisis: The case of Turkey." Review of World Economics no. 118 (2):259-280.

Dudine, Paolo, and João Tovar Jalles. 2018. "How Buoyant is the Tax System? New Evidence from a Large Heterogeneous Panel." Journal of International Development no. 30 (6):961-991.

Durkaya, Mehmet, and Servet Ceylan. 2006. "Vergi Gelirleri ve Ekonomik Büyüme." Maliye Dergisi no. 150:79-89.

Ergil, Doğu. 1975. "Class Conflict and Turkish Transformation (1950-1975)." Studia Islamica (41):137161. doi: 10.2307/1595402.

Evrensel, Ayse Y. 2004. "IMF programs and financial liberalization in Turkey." Emerging Markets Finance and Trade no. 40 (4):5-19.

Finefrock, Michael M. 1981. "Laissez-faire, the 1923 Izmir economic congress and early Turkish developmental policy in political perspective." Middle Eastern Studies no. 17 (3):375-392.

Gök, Musa, Özgür Biyan, and Sevda Akar. 2015. "Vergilemede Adalet İlkesinin Anayasal Temelleri Ve Uygulamaya Yansimalari: Seçilmiş Oecd Ülkeleri Açisindan Karşilaştirmali Bìr Analiz." Marmara Universitesi iktisadi ve Idari Bilimler Dergisi no. 34 (1):269 - 292.

Günçavdı, Öner, Michael Bleaney, and Andrew McKay. 1998. "Financial liberalisation and private investment: evidence from Turkey." Journal of Development Economics no. 57 (2):443-455.

Hausman, Jerry A, and Agustin J Ros. 2013. "An econometric assessment of telecommunications prices and consumer surplus in Mexico using panel data." Journal of Regulatory Economics no. 43 (3):284-304.

Kakinaka, Makoto, and Rodrigo M Pereira. 2006. "A new measurement of tax progressivity." International University of Japan, Graduate School of International Relations Working Paper EDP06-7.

Kakwani, Nanak C. 1977. "Measurement of Tax Progressivity: An International Comparison." The Economic Journal no. 87 (345):71-80. doi: 10.2307/2231833.

Kaplanoglou, Georgia, and David Michael Newbery. 2003. "Indirect taxation in Greece: evaluation and possible reform." International Tax and Public Finance no. 10 (5):511-533.

Karacimen, Elif. 2014. "Financialization in Turkey: The case of consumer debt." Journal of Balkan and Near Eastern Studies no. 16 (2):161-180.

Keller, Wouter Jacques, and Jan Van Driel. 1985. "Differential consumer demand systems." European Economic Review no. 27 (3):375-390.

Keynes, John Maynard. 1936. The General Theory of Employment, Interest and Money.

Köse, Ahmet Haşim, and A Erinç Yeldan. 1998. "Turkish economy in the 1990s: An assessment of fiscal policies, labor markets and foreign trade." New Perspectives on Turkey no. 18:51-78.

Kraan, Dirk-Jan, Daniel Bergvall, and lan Hawkesworth. 2007. "Budgeting in Turkey." OECD Journal on Budgeting no. 7 (2):7-58.

Lewis, Jeffrey D., and Shujiro Urata. 1984. "Anatomy of a balance-of-payments crisis: Application of a computable general equilibrium model to Turkey, 1978-1980." Economic Modelling no. 1 (3):281-303. doi: https://doi.org/10.1016/0264-9993(84)90019-1.

Leyaro, Vincent, Oliver Morrissey, and Trudy Owens. 2010. "Food prices, tax reforms and consumer Welfare in Tanzania 1991-2007." International Tax and Public Finance no. 17 (4):430-450.

Leybourne, Stephen J, and Paul Newbold. 2003. "Spurious rejections by cointegration tests induced by structural breaks." Applied Economics no. 35 (9):1117-1121.

Mansfield, Charles Y. 1972. "Elasticity and Buoyancy of a Tax System: A Method Applied to Paraguay." IMF Staff Papers no. 19 (2):425.

Mercenier, Jean, and Erinc Yeldan. 1997. "On Turkey's trade policy: Is a customs union with Europe enough?" European Economic Review no. 41 (3-5):871-880.

Morrissey, Oliver. 1995. "Political commitment, institutional capacity and tax policy reform in Tanzania." World Development no. 23 (4):637-649. doi: https://doi.org/10.1016/0305750X(94)00148-R. 
Mucuk, Mehmet, and Volkan Alptekin. 2008. "Türkiye'de Vergi ve Ekonomik Büyüme İlişkisi: VAR Analizi (1975-2006)." Maliye Dergisi no. 155:159-174.

OECD. Revenue Statistics OECD Member Countries: Comparative tables. OECD.Stat 2017 [cited 25.11.2017. Available from http://stats.oecd.org/.

Önis, Ziya. 2006. "Varieties and crises of neoliberal globalisation: Argentina, Turkey and the imf." Third World Quarterly no. 27 (2):239-263. doi: 10.1080/01436590500432366.

Orhangazi, Özgür. 2014. "Capital Flows and Credit Expansions in Turkey." Review of Radical Political Economics no. 46 (4):509-516.

Pesaran, M Hashem, and Yongcheol Shin. 1998. "An autoregressive distributed-lag modelling approach to cointegration analysis." Econometric Society Monographs no. 31:371-413.

Pesaran, M Hashem, Yongcheol Shin, and Richard J Smith. 2001. "Bounds testing approaches to the analysis of level relationships." Journal of applied econometrics no. 16 (3):289-326.

Phillips, Peter CB. 1995. "Fully modified least squares and vector autoregression." Econometrica: Journal of the Econometric Society:1023-1078.

Pomerleau, Kyle. 2017. International Tax Competitiveness Index 2016. Tax Foundation.

Ravn, Morten, and Harald Uhlig. 2001. On Adjusting the HP-Filter for the Frequency of Observations. CESifo Group Munich.

Rittenberg, Libby. 1993. "Exchange rate policy and price level changes: Casualty tests for Turkey in the post-liberalisation period." The Journal of Development Studies no. 29 (2):245-259.

Rodrik, Dani. 1990. Premature liberalization, incomplete stabilization: the Ozal decade in Turkey. National Bureau of Economic Research.

Schneider, Friedrich. 2013. "Size and development of the shadow economy of 31 European and 5 other OECD countries from 2003 to 2013: a further decline." Johannes Kepler Universität, Linz:5-7.

Schneider, Friedrich. 2015. "Size and Development of the Shadow Economy of 31 European and 5 Other OECD Countries from 2003 to 2014: Different Developments?" Journal of SelfGovernance \& Management Economics no. 3 (4).

Takim, Abdullah, and Ensar Yilmaz. 2010. "Economic policy during Ataturk's era in Turkey (19231938)." African Journal of Business Management no. 4 (4):549.

Tiffin, Richard, and Matthew Salois. 2015. "The distributional consequences of a fiscal food policy: evidence from the UK." European Review of Agricultural Economics no. 42 (3):397-417. doi: 10.1093/erae/jbu027.

Türkan, Ercan. 2009. Son vergi düzenlemeleri ile ortaya çıkan fiyat indirimleri tüketiciye yansıtıldı mı? : Central Bank of Republic of Turker.

TURKSTAT. Consumption Expenditure Statistics 2016 [cited 14.04.2016. Available from https://biruni.tuik.gov.tr/medas/?kn=132\&locale=en.

Wagner, Adolph. 1958. "Three extracts on public finance." In Classics in the theory of public finance, 1-15. Springer.

West, Sarah E, and Roberton C Williams. 2004. "Estimates from a consumer demand system: implications for the incidence of environmental taxes." Journal of Environmental Economics and management no. 47 (3):535-558.

WorldBank. DataBank World Development Indicators Country Turkey 2017a [cited 20.06.2017. Available from http://databank.worldbank.org/data/reports.aspx?source=2\&country=TUR.

WorldBank. 2017b. GDP ranking, PPP based.

Yeldan, A Erinc. 1989. "Structural adjustment and Trade in Turkey: Investigating the alternatives "beyond export-led growth"." Journal of Policy Modeling no. 11 (2):273-296.

Yeldan, Erinc. 2006. "Neoliberal global remedies: from speculative-led growth to IMF-led crisis in Turkey." Review of Radical Political Economics no. 38 (2):193-213.

Yılmaz, Kamil. 2011. "The EU-Turkey Customs Union Fifteen Years Later: Better, Yet not the Best Alternative." South European Society and Politics no. 16 (2):235-249. doi: 10.1080/13608746.2011.577941. 
Yuksel, Canan, Harun Alp, Y Soner Baskaya, and Mustafa Kılınc. 2011. "Türkiye için Hodrick-Prescott Filtresi Düzgünleştirme Parametresi Tahmini (Estimating Hodrick-Prescott Filter Smoothing Parameter for Turkey)." Central Bank of Turkey, Research Notes in Economics.

\section{APPENDIX}

1. GDP and Taxes Over Time

Figure 11: GDP and Taxes (at Level), $1924-2016$

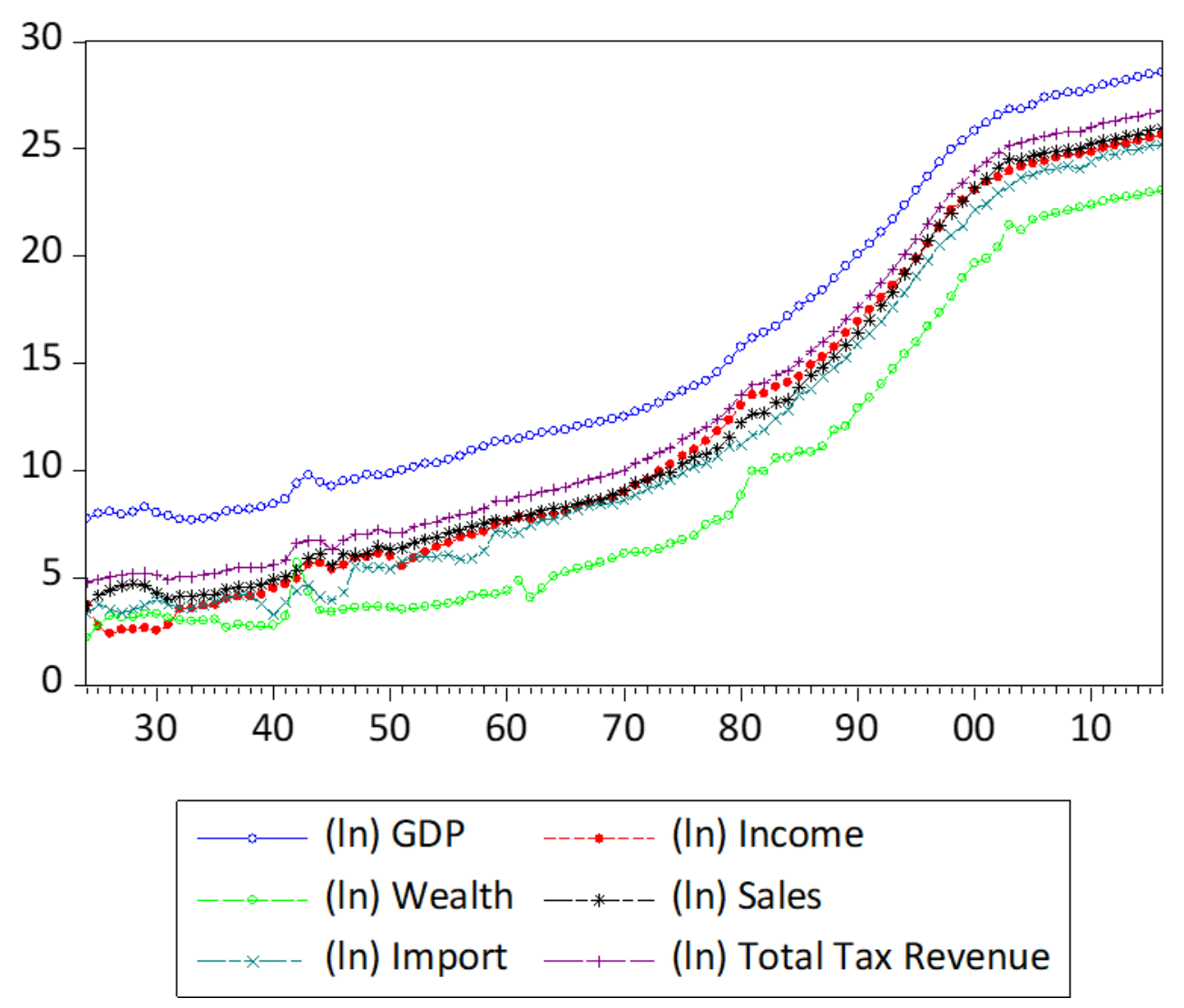

Data from General Directorate of Budget and Fiscal Control, Budget Figures and Budget Realization,

Budget Figures since 1924. Last Access: 23.11.2017. 


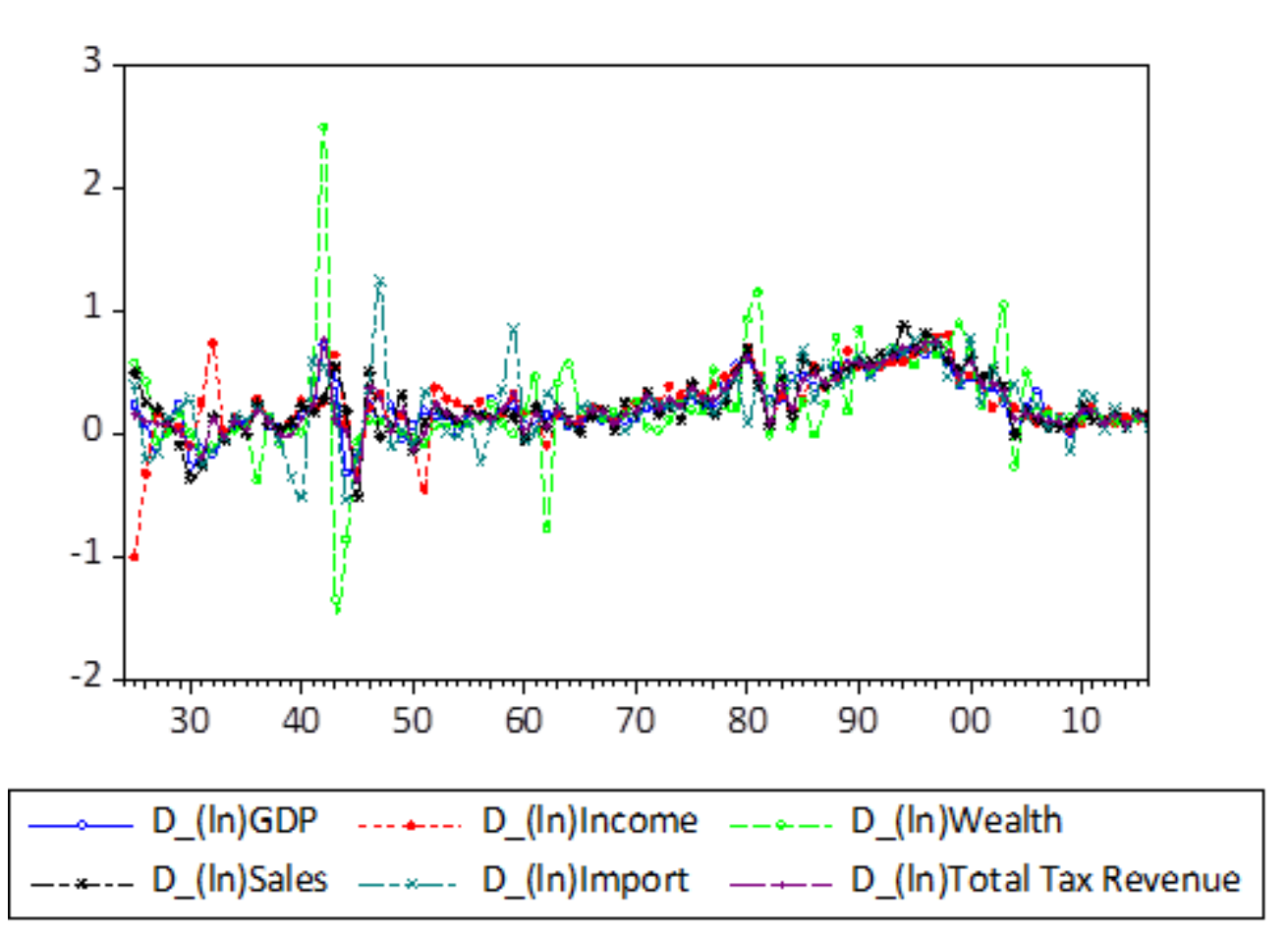

Data from General Directorate of Budget and Fiscal Control, Budget Figures and Budget Realization,

Budget Figures since 1924. Last Access: 23.11.2017.

2. HP- Filtered Series

Figure 13: HP-Filtered Series, 1924-2016 
CYC_GDP

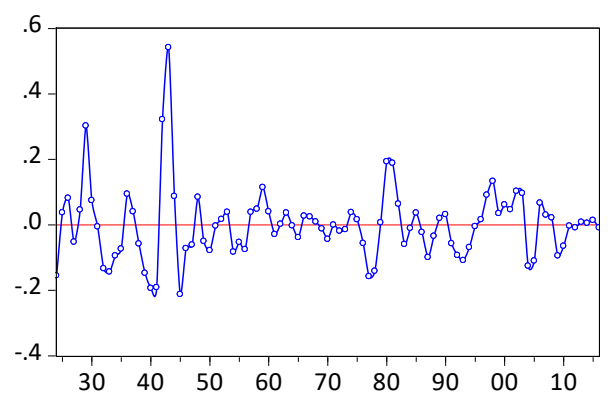

CYC_WEALTH

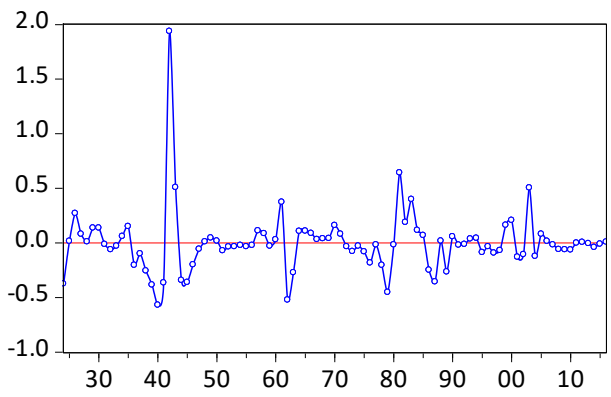

CYC_IMPORT

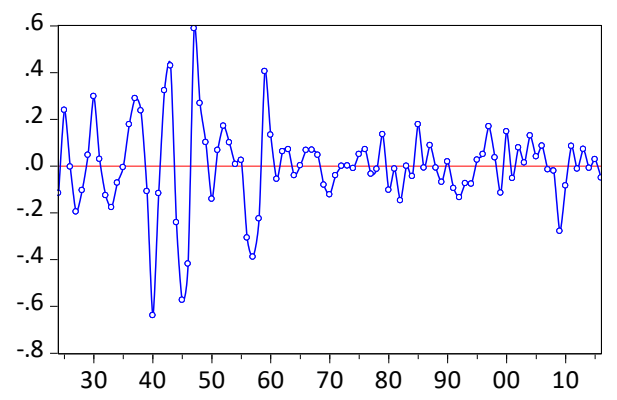

CYC_INCOME

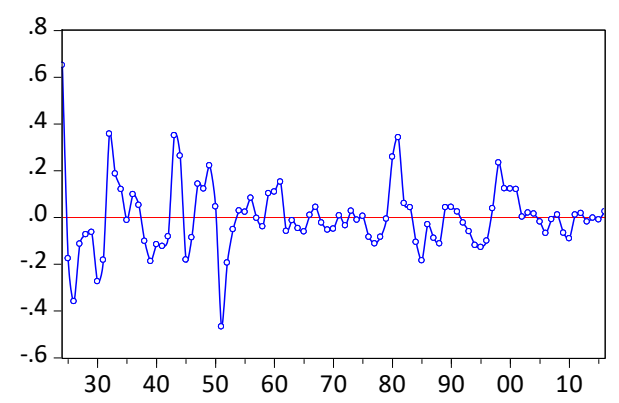

CYC SALES

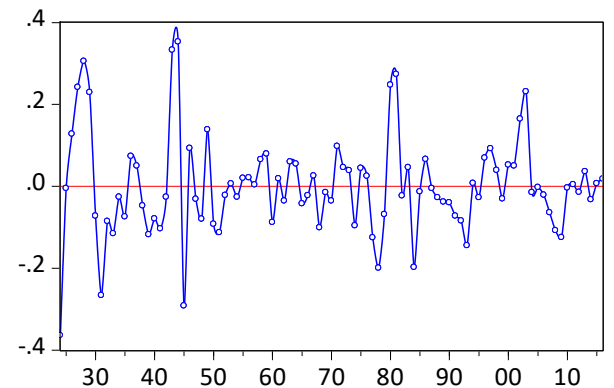

CYC_TOTALTAX

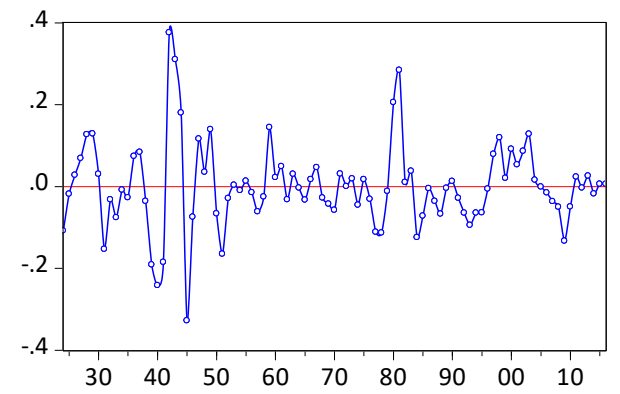

3. Cointegration Results

3.1. ARDL Model Bound Tests

3.1.1. Income Tax and GDP

\begin{tabular}{lccrr} 
F-Bounds Test & & \multicolumn{3}{c}{ Null Hypothesis: No levels relationship } \\
\hline \hline Test Statistic & Value & Signif. & $\mathrm{l}(0)$ & $\mathrm{I}(1)$ \\
\hline \hline F-statistic & 5.379181 & $10 \%$ & 4.05 & 4.49 \\
$\mathrm{k}$ & 1 & $5 \%$ & 4.68 & 5.15 \\
& & $2.5 \%$ & 5.3 & 5.83 \\
& & $1 \%$ & 6.1 & 6.73 \\
\hline \hline
\end{tabular}


3.1.2. Wealth Tax and GDP

\begin{tabular}{lccrr} 
F-Bounds Test & & Null Hypothesis: No levels relationship \\
\hline \hline Test Statistic & Value & Signif. & $\mathrm{I}(0)$ & $\mathrm{I}(1)$ \\
\hline \hline F-statistic & 4.444312 & $10 \%$ & 4.05 & 4.49 \\
k & 1 & $5 \%$ & 4.68 & 5.15 \\
& & $2.5 \%$ & 5.3 & 5.83 \\
& & $1 \%$ & 6.1 & 6.73 \\
\hline \hline
\end{tabular}

3.1.3. Sales Tax and GDP

F-Bounds Test Null Hypothesis: No levels relationship

\begin{tabular}{lcrrr}
\hline \hline Test Statistic & Value & Signif. & $\mathrm{I}(0)$ & $\mathrm{I}(1)$ \\
\hline \hline F-statistic & 4.442161 & $10 \%$ & 4.05 & 4.49 \\
$\mathrm{k}$ & 1 & $5 \%$ & 4.68 & 5.15 \\
& & $2.5 \%$ & 5.3 & 5.83 \\
& & $1 \%$ & 6.1 & 6.73 \\
\hline \hline
\end{tabular}

3.1.4 Import Tax and GDP

\begin{tabular}{lccrr} 
F-Bounds Test & & Null Hypothesis: No levels relationship \\
\hline \hline Test Statistic & Value & Signif. & $\mathrm{I}(0)$ & $\mathrm{I}(1)$ \\
\hline \hline F-statistic & 6.261327 & $10 \%$ & 4.05 & 4.49 \\
$\mathrm{k}$ & 1 & $5 \%$ & 4.68 & 5.15 \\
& & $2.5 \%$ & 5.3 & 5.83 \\
& & $1 \%$ & 6.1 & 6.73 \\
\hline \hline
\end{tabular}

3.1.5. Total Tax Revenue and GDP

\begin{tabular}{lcccr} 
F-Bounds Test & & \multicolumn{3}{c}{ Null Hypothesis: No levels relationship } \\
\hline \hline Test Statistic & Value & Signif. & $\mathrm{I}(0)$ & $\mathrm{I}(1)$ \\
\hline \hline F-statistic & $8.124749 \ldots$ & $10 \%$ & 3.02 & 3.51 \\
k & 1 & $5 \%$ & 3.62 & 4.16 \\
& & $2.5 \%$ & 4.18 & 4.79 \\
& & $1 \%$ & 4.94 & 5.58 \\
\hline \hline
\end{tabular}


Results

3.2.1. Income Tax and GDP

\begin{tabular}{lll}
\hline \hline & Value & Prob. $^{*}$ \\
\hline Engle-Granger tau-statistic & -9.405987 & 0.0000 \\
Engle-Granger z-statistic & -71.26119 & 0.0000 \\
\hline \hline
\end{tabular}

*MacKinnon (1996) p-values.

3.2.2. Wealth Tax and GDP

\begin{tabular}{lcl}
\hline \hline & Value & Prob. $^{*}$ \\
\hline Engle-Granger tau-statistic & -9.463265 & 0.0000 \\
Engle-Granger z-statistic & -177.4477 & 0.0000 \\
\hline \hline
\end{tabular}

*MacKinnon (1996) p-values.

3.2.3. Sales Tax and GDP

\begin{tabular}{lcl}
\hline \hline & Value & Prob. $^{*}$ \\
\hline Engle-Granger tau-statistic & -10.99221 & 0.0000 \\
Engle-Granger z-statistic & -102.8579 & 0.0000 \\
\hline \hline
\end{tabular}

*MacKinnon (1996) p-values.

3.2.4. Import Tax and GDP

\begin{tabular}{lcl}
\hline \hline & Value & Prob. $^{*}$ \\
\hline Engle-Granger tau-statistic & -10.07007 & 0.0000 \\
Engle-Granger z-statistic & -96.26181 & 0.0000 \\
\hline \hline
\end{tabular}

*MacKinnon (1996) p-values.

3.2.5. Total Tax Revenue and GDP

\begin{tabular}{lcl}
\hline \hline & Value & Prob. ${ }^{*}$ \\
\hline Engle-Granger tau-statistic & -12.74006 & 0.0000 \\
Engle-Granger z-statistic & -116.7104 & 0.0000 \\
\hline \hline
\end{tabular}

